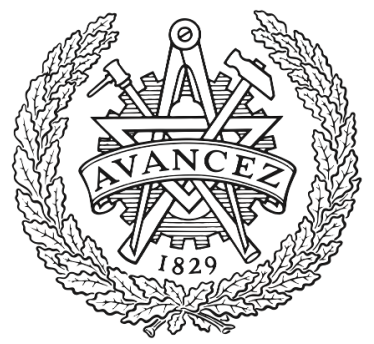

CHALMERS

UNIVERSITY OF TECHNOLOGY

\title{
Risk-based cost-benefit analysis for evaluating microbial risk mitigation in a drinking water system
}

Downloaded from: https://research.chalmers.se, 2023-04-26 13:37 UTC

Citation for the original published paper (version of record):

Bergion, V., Lindhe, A., Sokolova, E. et al (2018). Risk-based cost-benefit analysis for evaluating microbial risk mitigation in a drinking water

system. Water Research, 132: 111-123. http://dx.doi.org/10.1016/j.watres.2017.12.054

N.B. When citing this work, cite the original published paper. 


\section{Accepted Manuscript}

Risk-based cost-benefit analysis for evaluating microbial risk mitigation in a drinking water system

Viktor Bergion, Andreas Lindhe, Ekaterina Sokolova, Lars Rosén

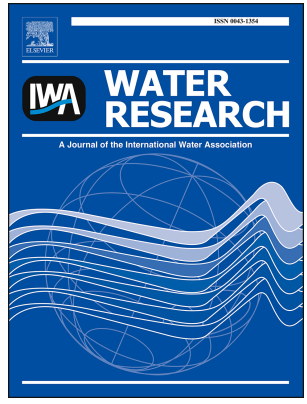

PII:

S0043-1354(17)31049-7

DOI:

10.1016/j.watres.2017.12.054

Reference:

WR 13452

To appear in: Water Research

Received Date: 13 July 2017

Revised Date: 31 October 2017

Accepted Date: 22 December 2017

Please cite this article as: Bergion, V., Lindhe, A., Sokolova, E., Rosén, L., Risk-based cost-benefit analysis for evaluating microbial risk mitigation in a drinking water system, Water Research (2018), doi: 10.1016/j.watres.2017.12.054.

This is a PDF file of an unedited manuscript that has been accepted for publication. As a service to our customers we are providing this early version of the manuscript. The manuscript will undergo copyediting, typesetting, and review of the resulting proof before it is published in its final form. Please note that during the production process errors may be discovered which could affect the content, and all legal disclaimers that apply to the journal pertain. 


\section{Risk-based decision model}

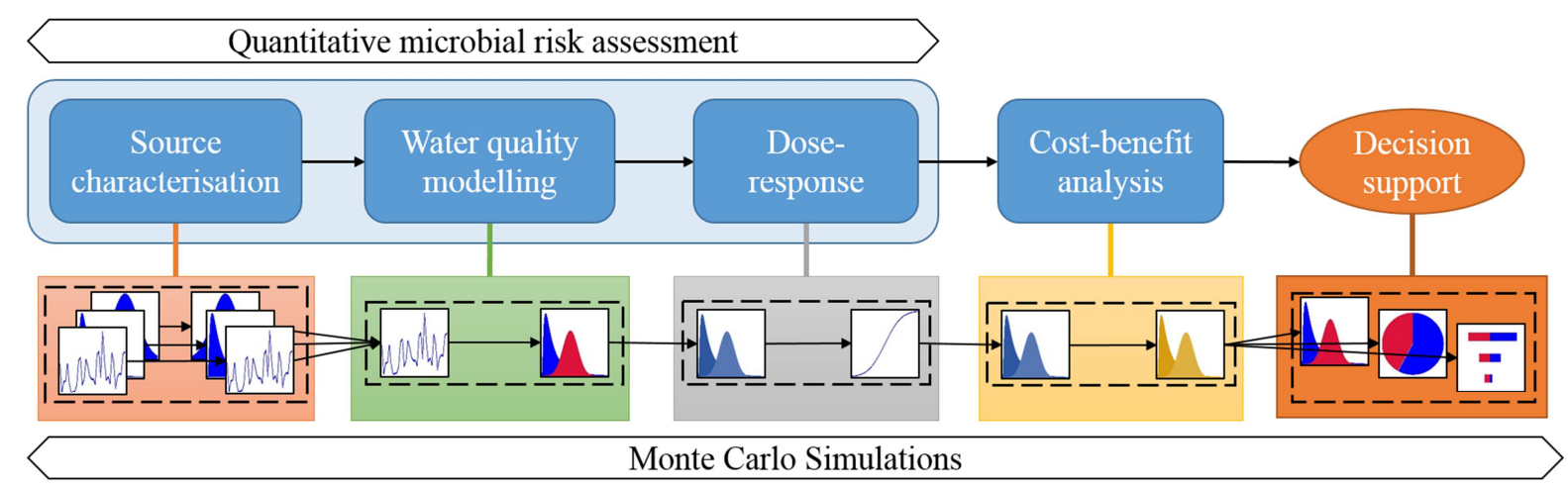




\section{Risk-based cost-benefit analysis for evaluating}

\section{2 microbial risk mitigation in a drinking water}

\section{3 system}

4 Viktor Bergion $^{\mathrm{a}^{*}}$, Andreas Lindhe $^{\mathrm{a}}$, Ekaterina Sokolova ${ }^{\mathrm{a}}$, Lars Rosén $^{\mathrm{a}}$

$5 \quad{ }^{a}$ Chalmers University of Technology, Department of Architecture and Civil Engineering

6 SE-41269 Gothenburg, Sweden

$7 \quad$ * Corresponding author, e-mail address: viktor.bergion@ chalmers.se

\section{Abstract}

Waterborne outbreaks of gastrointestinal diseases can cause large costs to society. Risk management needs to be holistic and transparent in order to reduce these risks in an effective manner. Microbial risk mitigation measures in a drinking water system were investigated using a novel approach combining probabilistic risk assessment and cost-benefit analysis. Lake Vomb in Sweden was used to exemplify and illustrate the risk-based decision model. Four mitigation alternatives were compared, where the first three alternatives, A1-A3, represented connecting 25,50 and $75 \%$, respectively, of on-site wastewater treatment systems in the catchment to the municipal wastewater treatment plant. The fourth alternative, A4, represented installing a UV-disinfection unit in the drinking water treatment plant. Quantitative microbial risk assessment was used to estimate the positive health effects in terms of quality adjusted life years (QALYs), resulting from the four mitigation alternatives.

The health benefits were monetised using a unit cost per QALY. For each mitigation alternative, the net present value of health and environmental benefits and investment, 
maintenance and running costs was calculated. The results showed that only A4 can reduce the risk (probability of infection) below the World Health Organization guidelines of $10^{-4}$ infections per person per year (looking at the $95^{\text {th }}$ percentile). Furthermore, all alternatives resulted in a negative net present value. However, the net present value would be positive (looking at the $50^{\text {th }}$ percentile using a $1 \%$ discount rate) if non-monetised benefits (e.g. increased property value divided evenly over the studied time horizon and reduced microbial risks posed to animals), estimated at 800-1200 SEK (€100-150) per connected on-site wastewater treatment system per year, were included. This risk-based decision model creates a robust and transparent decision support tool. It is flexible enough to be tailored and applied to local settings of drinking water systems. The model provides a clear and holistic structure for decisions related to microbial risk mitigation. To improve the decision model, we suggest to further develop the valuation and monetisation of health effects and to refine the propagation of uncertainties and variabilities between the included methods.

Keywords: cost-benefit analysis (CBA), decision support, drinking water, quality adjusted life year (QALY), quantitative microbial risk assessment (QMRA), water quality modelling 


\section{Introduction}

Risk management of drinking water systems (DWSs) is an iterative process including risk assessment and risk mitigation (i.e. risk treatment) (ISO 2009). To be effective in providing safe drinking water supply, the risk management must comprise the entire system, from catchment to consumer. If the risks are unacceptable, risk mitigation measures should be implemented, and alternatives for risk mitigation evaluated. Water Safety Plans procedures, developed by the World Health Organization (WHO), can serve as a risk management strategy for water providers (Bartram et al. 2009). However, in order to allocate societal resources for risk mitigation in an efficient manner, the economic dimension of risk levels and possible risk mitigation measures must be considered (WHO 2011).

Risks related to DWSs have been extensively discussed in the literature (e.g. Beuken et al. 2008, Keller and Wilson 1992, WHO 2011). Health risks in DWSs can be related to chemical, microbial and radiological hazards (WHO 2011). In this paper, the microbial risks are the main focus. Microbial risks in the form of pathogenic microorganisms can originate from faecal sources (Dufour et al. 2012, Ferguson et al. 2009) related to humans (municipal wastewater treatment plants (WWTPs) or on-site wastewater treatment systems (OWTSs) on private properties) or animals (wild animals, domestic grazing animals or use of manure on cropland). Pathogens in DWSs can cause endemic waterborne illness (Payment and Hunter 2001) as well as waterborne outbreaks of gastrointestinal diseases, resulting in high costs for the society (Corso et al. 2003, Larsson et al. 2014). The WHO pointed out that the societal costs for endemic waterborne illness and related gastrointestinal disease are commonly underestimated (WHO 2001).

Quantitative microbial risk assessment (QMRA) has been applied to DWSs in various settings (Haas et al. 2014, WHO 2016) in order to assess the risk in relation to an acceptable or 
tolerable risk level. The result from a QMRA is typically reported as probability of infection, disability adjusted life years (DALYs) or quality adjusted life years (QALYs). Both DALYs and QALYs are health metrics that combine mortality and morbidity. Drinking water producers commonly look at the (WHO) for guidance and the suggested risk levels of an annual probability of infection of $10^{-4}$ per person per year, and DALYs of $10^{-6}$ per person per year (WHO 2011).

To make informed decisions on which risk mitigation measure to implement in order to use societal resources effectively, the alternatives need to be compared. Comprehensive lists and procedures for identifying risk mitigation measures (e.g. Åström and Pettersson 2010, NZMH 2014, Rosén et al. 2010) are available. Decision support systems or decision models such as cost-effectiveness analysis (CEA) and multi-criteria decision analysis (MCDA) can aid decision makers in comparing the alternatives. If there are no regulations regarding acceptable risk levels, other evaluation methods might be needed in order to justify the implementation of risk mitigation measures. Cost-benefit analysis (CBA) provides a robust well-established decision support approach to investigate the measure that is the most profitable or least costly (if a certain risk level is required) for society (Boardman et al. 2011, Cameron et al. 2011).

Comparing mitigation measures directed at different parts of the supply system and identifying the options most profitable for society are key steps towards a holistic and sustainable risk management approach. Adopting holistic risk management also enables the multi-barrier approach emphasised by the WHO (2011). Using CBA as a basis for decision support helps to allocate monetary resources in an efficient manner providing possibilities to compare mitigation measures with interventions in other sectors (e.g. food, health care, traffic and environmental risk management). CBA facilitates optimisation of the societal resources by comparing economic metrics, such as net present value (NPV), and performing distributional analysis (Cameron et al. 2011). CBA also helps highlight the societal benefits of 
reducing microbial risks in DWSs and creates a systematic and transparent decision support tool.

Different frameworks for combining risk management, decision making process and CBA in the drinking water context have been investigated (e.g. Assmuth et al. 2016, Rizak et al. 2003). Despite the aforementioned implementations, there are few, if any, methods that use a probabilistic quantitative risk-based approach to create decision support in the form of a CBA for microbial risk management in DWSs. To include an economic dimension and to perform a CBA in this way is uncommon, even though the need is emphasised by the WHO (WHO 2001).

Aim

In this study we develop a method for creating a systematic, holistic and transparent decision support for microbial risk management in DWSs. We present a novel CBA approach from catchment to consumer. More in detail, we perform a CBA using a combination of water quality modelling and QMRA to compare microbial risk mitigation alternatives in a DWS. The methodology is exemplified using Lake Vomb in the south of Sweden. Different alternatives of removing OWTSs are compared to installation of an additional treatment step in the drinking water treatment plant (DWTP). We also highlight the choices that needs to be made in the CBA-model, and what implications these might have on the outcome of the CBA.

\section{Risk-based decision model}

The suggested approach for combining the methods for QMRA and CBA is presented as a decision model in Figure 1. The four major compartments are: (i) source characterisation, (ii) water quality modelling, (iii) dose-response, and (iv) CBA. The source characterisation provides input to the water quality modelling, and the water quality modelling provides input to the dose-response. The QMRA framework, including (i), (ii) and (iii), describes the entire 
111 risk chain in the DWS and provides input for the CBA. Epistemic uncertainties (associated

112 with lack of knowledge) and aleatory uncertainties (associated with natural variations) in all

113 compartments are incorporated into the model by means of Monte Carlo (MC) simulations.

114 The combination of methods aims to enable an estimation of the microbial risk in the DWS as

115 well as an estimation of the effect of risk reduction measures and their societal profitability.

116 Hence, the decision model can serve as a tool within the water safety plan framework. When

117 analysing different mitigation measures, each compartment of the decision model needs to be

118 executed. Detailed method descriptions of each compartment are presented in sections 3.2-

119 3.4. It should be noted that this decision model is generic, and the applied methods in each

120 case study should be selected to fit the specific context of the analysed DWS.

121

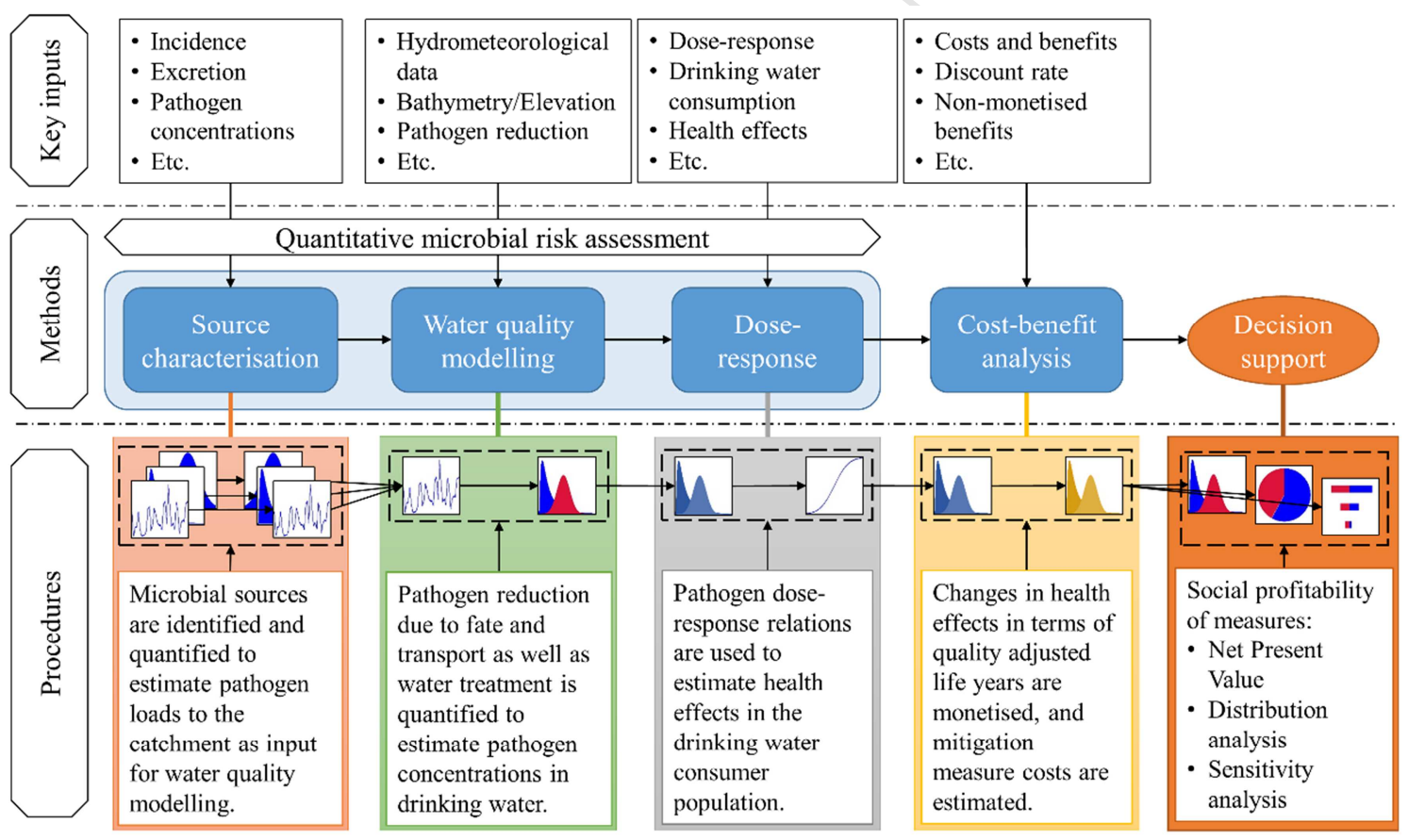

122 Figure 1. Risk-based decision model combining methods for evaluating and comparing

123 microbial risk mitigation measures. 
124

125

126

127

128

129

130

131

132

133

134

135

136

137

\section{Methods}

\subsection{Lake Vomb}

Lake Vomb is a small lake in Scania, the southernmost part of Sweden, providing 330,000 consumers with drinking water. The average water depth is $6.6 \mathrm{~m}$, and the maximum depth is $16 \mathrm{~m}$. Three major tributaries discharge into Lake Vomb: Borstbäcken, Torpsbäcken and Björkaån draining 26, 42 and $340 \mathrm{~km}^{2}$, respectively. There are approximately 2800 OWTSs in the catchment (Norwegian Water BA 2009) posing a risk to the drinking water source. Other sources of microbial risks are e.g. WWTP, fertilisation using manure, grazing animals, wild animals. Raw water is extracted from Lake Vomb and artificially infiltrated into a glaciofluvial aquifer and then treated using conventional treatment consisting of rapid sand filtration and chlorination (Norwegian Water BA 2009). Figure 2 illustrates the case study area.

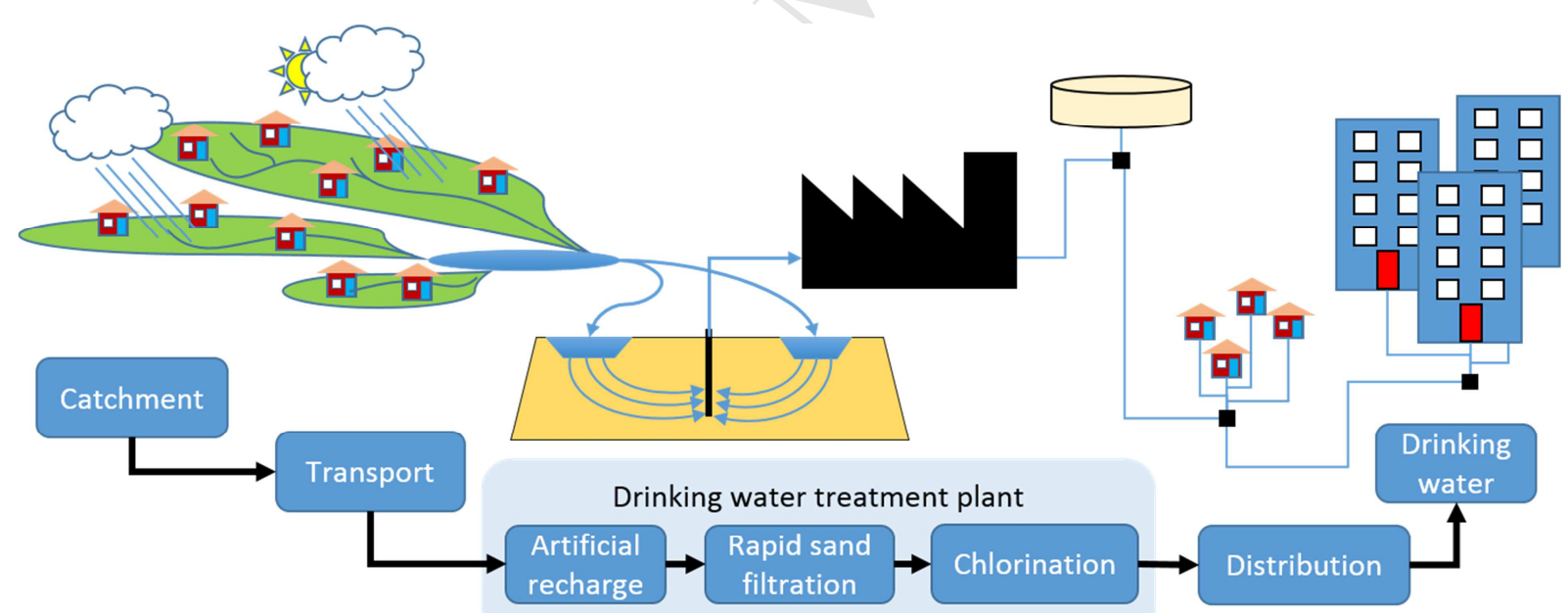

Figure 2 Schematic illustration of Lake Vomb drinking water system.

Microbial risk mitigation alternatives in different parts of the DWS were chosen to illustrate how the risk-based decision model can be used. The mitigation alternatives also reflect the contemporary trends in Sweden regarding OWTSs management and an increase in installation of UV-disinfection in DWTPs. Three of the analysed alternatives represent connection of 
different proportions $(25,50$ and $75 \%$, respectively) of the OWTSs in the catchment to the municipal WWTP. The costs for the alternatives were based on connection of clusters of closely located OWTSs. However, the pathogen load from these OWTSs was assumed to be removed evenly across the different types of OWTSs and geographically across the catchment area. This assumption was made because of the short transport time in the catchment (Sundahl et al. 2008). The fourth alternative was to install UV-disinfection at the DWTP at Lake Vomb.

The four decision alternatives and one reference alternative were analysed:

- Reference alternative (A-Ref) - Continuation of the present state.

- Alternative 1 (A1) - Connecting $25 \%$ (621) of the OWTSs to the local WWTP.

- Alternative 2 (A2) - Connecting $50 \%$ (1240) of the OWTSs to the local WWTP.

- Alternative 3 (A3) - Connecting $75 \%(1861)$ of the OWTSs to the local WWTP.

- Alternative 4 (A4) - An additional barrier, UV-disinfection, is installed at the DWTP.

\subsection{Quantitative microbial risk assessment (QMRA)}

The QMRA methodology (Haas et al. 2014) was used for quantifying the health effects related to the reference alternative and the microbial risk mitigation alternatives. All inputs for the QMRA are listed in Table 1; input distributions represent both epistemic uncertainties and aleatory uncertainties.

\subsubsection{Source characterisation}

Human pathogens in wastewater from OWTS were quantified as described by Ottoson and Stenström (2003). It was assumed that the population was large enough to have pathogens present continuously, and that the entire pathogen load was evenly spread throughout the catchment. Three reference pathogens were used, one for each of the pathogen groups: Cryptosporidium for protozoa; Campylobacter for bacteria; and norovirus for viruses. The 
was calculated as:

$$
C_{\text {Tributary }}=\frac{I_{\text {Path }} \cdot U \cdot D_{\text {Path }} \cdot F P \cdot C \cdot P}{365 \cdot 10^{5} \cdot F_{\text {Tributary }}}
$$

171 per person per day; $C$ (pathogens $/ g$ ) was the pathogen concentration in faeces when infected;

$172 P$ (persons) was the number of persons that are using OWTSs in the sub-basin; and $F_{\text {Tributary }}$

173 (L/day) was the average daily flow for each tributary.

Table 1 Inputs for the quantitative microbial risk assessment.

\begin{tabular}{|c|c|c|c|c|}
\hline Input & Unit & Abbr. & Distr. & Parameters \\
\hline \multicolumn{5}{|c|}{ General inputs } \\
\hline Pers. connected to OWTSs ${ }^{a}$ & $\#$ & $P$ & PV & $\begin{array}{l}\text { ARef }=6215, A 1=4661, A 2=3107, A 3=1554, \\
\text { A4 }=6215\end{array}$ \\
\hline Factor of underreporting ${ }^{b}$ & - & $\mathrm{U}$ & PV & 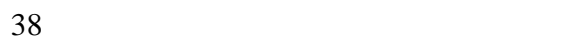 \\
\hline Faecal production ${ }^{\mathrm{c}}$ & $\mathrm{g}$ & $F P$ & $\mathrm{~N}$ & $\mathrm{P} 05=115.7, \mathrm{P} 95=144.2$ \\
\hline Red. in on-site sewage ${ }^{d}$ & $\log _{10}$ red. & $R_{O W T S}$ & PV & 0.72 \\
\hline Depth of unsat. zone ${ }^{\mathrm{e}}$ & $\mathrm{m}$ & $D p_{U Z}$ & $\mathrm{~T}$ & $\operatorname{Min}=1.2$, Mode $=1.5, \operatorname{Max}=2.4$ \\
\hline Length of satur. zone ${ }^{\mathrm{e}}$ & $\mathrm{m}$ & $L_{S Z}$ & $\mathrm{~T}$ & Min $=100$, Mode $=150$, Max $=250$ \\
\hline Drinking water consumption ${ }^{\mathrm{f}}$ & L/day & & $\mathrm{e}^{\mathrm{N}}$ & $\mathrm{N}(\mu=-0.299, \sigma=0.57)$ \\
\hline Average flow Björkaån ${ }^{\mathrm{g}}$ & L/day & $F_{\text {Biorka }}$ & PV & $3.21 * 10^{8}$ \\
\hline Average flow Torpsbäcken ${ }^{\mathrm{g}}$ & L/day & $F_{\text {Torps }}$ & PV & $3.46 * 10^{7}$ \\
\hline Average flow Borstbäcken ${ }^{\mathrm{g}}$ & L/day & $F_{\text {Borst }}$ & PV & $2.16 * 10^{7}$ \\
\hline \multicolumn{5}{|c|}{ Inputs for norovirus } \\
\hline Incidence $^{h}$ & Inf./10 $\mathrm{inh} / \mathrm{y}$ & $I_{\text {Noro }}$ & $\mathrm{G}$ & $\alpha=6.25, \beta=10.6$ \\
\hline Days excreting ${ }^{i}$ & days & $D_{\text {Noro }}$ & $\mathrm{LN}$ & $\mathrm{P} 01=13, \mathrm{P} 99=27, \mathrm{Loc}=0$ \\
\hline Path. conc. in faeces if inf. ${ }^{j}$ & $\log _{10}$ path./g & $C_{\text {Noro }}$ & $\mathrm{N}$ & $\mathrm{P} 01=5, \mathrm{P} 99=9$ \\
\hline Red. lake transp. Björkaån ${ }^{\mathrm{k}}$ & $\log _{10}$ red. & $R_{\text {Biork_Noro }}$ & $\mathrm{N}$ & $\mu=4.5, \sigma=0.12, \operatorname{Tr}: \operatorname{Min}=0$ \\
\hline Red. lake transp. Torpsbäcken ${ }^{\mathrm{k}}$ & $\log _{10}$ red. & $R_{\text {Torp_Noro }}$ & $\mathrm{N}$ & $\mu=4.5, \sigma=0.11, \operatorname{Tr}: \operatorname{Min}=0$ \\
\hline Red. lake transp. Borstbäcken ${ }^{\mathrm{k}}$ & $\log _{10}$ red. & $R_{\text {Borst_Noro }}$ & $\mathrm{N}$ & $\mu=4.6, \sigma=0.10, \operatorname{Tr}: \operatorname{Min}=0$ \\
\hline Red. in unsatur. zone ${ }^{1}$ & $\log _{10}$ red./m & $R_{U Z / m_{-} \text {Noro }}$ & $\mathrm{T}$ & Min $=0.05$, Mode $=0.3, \operatorname{Max}=1$ \\
\hline Red. in satur. zone ${ }^{\mathrm{m}}$ & $\log _{10}$ red./m & $R_{S Z \_N o r o}$ & $\mathrm{LN}$ & $\mu=6.6587, \sigma=5.5366$ \\
\hline Red. in conv. treatm. ${ }^{n}$ & $\log _{10}$ red. & $R_{C T \_ \text {Noro }}$ & $\mathrm{T}$ & $\operatorname{Min}=0.4$, Mode $=0.5, \operatorname{Max}=0.6$ \\
\hline Red. in UV-treatm. ${ }^{\circ}$ & $\log _{10}$ red. & $R_{U V_{-} \text {Noro }}$ & PV & 4.2 \\
\hline Infectivity ${ }^{p}$ & & $m_{\text {Noro }}$ & EBP & $\alpha=0.04, \beta=0.055$ \\
\hline DALYs per infection ${ }^{\mathrm{q}}$ & DALY/inf & $D_{\text {Noro }}$ & $\mathrm{PV}$ & 0.000716 \\
\hline QALYs per infection ${ }^{r}$ & QALY/inf & $Q_{\text {Noro }}$ & PV & 0.0009 \\
\hline \multicolumn{5}{|c|}{ Inputs for Campylobacter } \\
\hline Incidence $^{h}$ & Inf./10 $5 \mathrm{inh} / \mathrm{y}$ & $I_{\text {Camp }}$ & $\mathrm{G}$ & $\alpha=64.6, \beta=1.27$ \\
\hline Days excreting ${ }^{\mathrm{i}}$ & days & $D_{\text {Camp }}$ & $\mathrm{LN}$ & $\mathrm{P} 01=13, \mathrm{P} 99=27, \mathrm{Loc}=0$ \\
\hline Path. conc. in faeces if inf. ${ }^{j}$ & $\log _{10}$ path./g & $C_{\text {Camp }}$ & $\mathrm{N}$ & $\mathrm{P} 01=4, \mathrm{P} 99=10$ \\
\hline Red. lake transp. Björkaån ${ }^{\mathrm{k}}$ & $\log _{10}$ red. & $R_{\text {Biork Camp }}$ & $\mathrm{N}$ & $\mu=5.5, \sigma=0.40, \operatorname{Tr}: \operatorname{Min}=0$ \\
\hline Red. lake transp. Torpsbäcken ${ }^{\mathrm{k}}$ & $\log _{10}$ red. & $R_{\text {Torp_Camp }}$ & $\mathrm{N}$ & $\mu=5.6, \sigma=0.38, \operatorname{Tr}: \operatorname{Min}=0$ \\
\hline Red. lake transp. Borstbäcken ${ }^{\mathrm{k}}$ & $\log _{10}$ red. & $R_{\text {Borst Camp }}$ & $\mathrm{N}$ & $\mu=5.9, \sigma=0.29$, Tr: Min $=0$ \\
\hline Red. in unsatur. Zone ${ }^{1}$ & $\log _{10}$ red./m & $R_{U Z / m_{-} \text {Camp }}$ & $\mathrm{T}$ & Min $=0.05$, Mode $=0.5, \operatorname{Max}=1$ \\
\hline Red. in satur. Zone ${ }^{1}$ & $\log _{10}$ red./m & $R_{S Z / m_{-} \text {Camp }}$ & $\mathrm{T}$ & Min $=0.001$, Mode $=0.05, \operatorname{Max}=1$ \\
\hline Red. in conv. treatm. ${ }^{n}$ & $\log _{10}$ red. & $R_{C T \text { Camp }}$ & $\mathrm{T}$ & $\operatorname{Min}=0.2$, Mode $=0.25, \operatorname{Max}=0.3$ \\
\hline Red. in UV-treatm. ${ }^{\circ}$ & $\log _{10}$ red. & $R_{U V \text { Camp }}$ & PV & 5.3 \\
\hline Infectivity $\mathrm{p}^{\mathrm{p}}$ & - & $m_{\text {Camp }}$ & EBP & $\alpha=0.024, \beta=0.011$ \\
\hline
\end{tabular}




\begin{tabular}{|c|c|c|c|c|}
\hline $\begin{array}{l}\text { DALYs per infection }{ }^{\mathrm{q}} \\
\text { QALYs per infection }\end{array}$ & $\begin{array}{l}\text { DALY/inf } \\
\text { QALY/inf }\end{array}$ & $\begin{array}{l}D_{\text {Camp }} \\
Q_{\text {Camp }}\end{array}$ & $\begin{array}{l}\text { PV } \\
\text { PV }\end{array}$ & $\begin{array}{l}0.00328 \\
0.0163 \\
\end{array}$ \\
\hline \multicolumn{5}{|c|}{ Inputs for Cryptosporidium } \\
\hline Incidence $^{f}$ & Inf./10 $5 \mathrm{inh} / \mathrm{y}$ & $I_{\text {Crvpt }}$ & $\mathrm{G}$ & $\alpha=5.43, \beta=0.228$ \\
\hline Days excreting ${ }^{g}$ & days & $D_{C r y p}$ & $\mathrm{LN}$ & $\mathrm{P} 01=5, \mathrm{P} 99=30, \mathrm{Loc}=0$ \\
\hline Path. conc. in faeces if inf. $\mathrm{j}$ & $\log _{10}$ path./g & $C_{\text {Cryp }}$ & $\mathrm{N}$ & $\mathrm{P} 01=7, \mathrm{P} 99=9$ \\
\hline Red. lake transp. Björkaån ${ }^{k}$ & $\log _{10}$ red. & $R_{\text {Bjork Cryp }}$ & $\mathrm{N}$ & $\mu=4.5, \sigma=0.12, \operatorname{Tr}: \operatorname{Min}=0$ \\
\hline Red. lake transp. Torpsbäcken ${ }^{\mathrm{k}}$ & $\log _{10}$ red. & $R_{\text {Torp }}$ Cryp & $\mathrm{N}$ & $\mu=4.6, \sigma=0.10, \operatorname{Tr}: \operatorname{Min}=0$ \\
\hline Red. lake transp. Borstbäcken ${ }^{k}$ & $\log _{10}$ red. & $R_{\text {Borst Cryp }}$ & $\mathrm{N}$ & $\mu=4.6, \sigma=0.095, \operatorname{Tr}: \operatorname{Min}=0$ \\
\hline Red. in unsatur. zone ${ }^{1}$ & $\log _{10}$ red./m & $R_{U Z / m \text { Cryp }}$ & $\mathrm{T}$ & Min $=0.05$, Mode $=0.5, \operatorname{Max}=1$ \\
\hline Red. in satur. zone ${ }^{l}$ & $\log _{10}$ red./m & $R_{S Z / m_{-} \text {Cryp }}$ & $\mathrm{T}$ & $\operatorname{Min}=0.001$, Mode $=0.05, \operatorname{Max}=1$ \\
\hline Red. in conv. treatm. ${ }^{n}$ & $\log _{10}$ red. & $R_{C T_{-} \text {Cryp }}$ & $\mathrm{T}$ & Min $=0.4$, Mode $=0.5$, Max $=0.6$ \\
\hline Red. in UV-treatm. ${ }^{\circ}$ & $\log _{10}$ red. & $R_{U V_{-} \text {Cryp }}$ & PV & 3 \\
\hline Infectivity ${ }^{p}$ & - & $m_{\text {Crvp }}$ & EBP & $\alpha=0.115, \beta=0.176$ \\
\hline DALYs per infection ${ }^{q}$ & DALY/inf & $D_{C r y p}$ & PV & 0.00267 \\
\hline QALYs per infection ${ }^{r}$ & QALY/inf & $Q_{\text {Cryp }}$ & PV & 0.0035 \\
\hline
\end{tabular}

a) 2.5 persons (Åström and Johansson 2015) per on-site wastewater treatment system.

b) Mead et al. (1999)

c) Wyman et al. (1978)

d) $\log _{10}$ reduction in on-site sewage was estimated using standard values for four types of systems, achieving $100 \%$ $99 \%, 95 \%, 50 \%$, respectively (SEPA 1991, 2002, 2003, 2008b), and the proportions of OWTS types.

e) Personal communication with B.M. Pott at Southern Sweden Water Supply (Sydvatten)

f) Westrell et al. (2006)

g) SMHI (2017)

h) Based on yearly incidence data 2006-2016 (PHAS 2017). Norovirus and Campylobacter: Best fit using ChiSquared, Cryptosporidium: Best fit using Kolmogorov-Smirnov. For norovirus: incidence was based on per season incidence and data from 2006-2012 was based on national data due to lack of regional estimates.

i) Norovirus: The Min/Median of the range of days shedding from Atmar et al. (2008) was chosen as P01/P99 respectively, Campylobacter and Cryptosporidium: Reported triangular Min/Max from Petterson et al. (2016) was chosen for P01/P99 respectively.

j) Norovirus: From Marshall et al. (2001) as reported in (Westrell 2004), Campylobacter and Cryptosporidium: Reported triangular Min/Max from Petterson et al. (2016) was chosen for P01/P99 respectively.

k) Distributions fitted from three years (2005-2007) of simulated daily $\log _{10}$ reduction from the hydrodynamic modelling. Tr=Truncation

1) Estimation based on expert judgement.

m) Reduction calculated using 10,000 MC iterations using a groundwater transport model estimating the removal due to attachment, inactivation and dilution (Åström et al. 2016, Schijven et al. 2006).

n) Norwegian Water BA (2009)

o) Calculated using Equation 7. UV-dose (fluence) was set to $400 \mathrm{~J} / \mathrm{m}^{2}$. The inactivation constant $(k)$ and intercept of the fluence axis (b) were set to $(k / b)(0.106 / 0),(0,293 / 0)$ and $(0,225 / 1.087)$ for norovirus, Campylobacter and Cryptosporidium respectively (Hijnen et al. 2006). Not to exceed the experimental range (Hijnen et al. 2006), the maximum $\log _{10}$ reduction was used for norovirus and Cryptosporidium.

p) Norovirus: Teunis et al. (2008), Campylobacter: Teunis et al. (2005), Cryptosporidium: Teunis et al. (2002).

q) Norovirus and Cryptosporidium: based on a re-analysis from Kemmeren et al. (2006), Campylobacter: based on Havelaar and Melse (2003).

r) Batz et al. (2014)

s) $P V=$ point value, $N=$ Normal distribution, $\mathrm{T}=$ triangular distribution, $\mathrm{e}^{\mathrm{N}}=$ exponential with a normal distribution in the exponent, $\mathrm{G}=$ Gamma distribution, $\mathrm{LN}=\mathrm{LogNormal}$ distribution, $\mathrm{EBP}=$ Exact Beta-Poisson distribution.

\subsubsection{Water quality modelling}

The pathogen concentrations at the raw water intake $\left(C_{R W}\right.$, pathogens $\left./ L\right)$ were calculated as:

$$
C_{R W}=\left(C_{\text {Borst }} \cdot 10^{-\left(R_{\text {OWTS }}+R_{\text {Borst }}\right)}\right)+\left(C_{\text {Torp }} \cdot 10^{-\left(R_{\text {OWIS }}+R_{\text {Torp }}\right)}\right)+\left(C_{\text {Bjorka }} \cdot 10^{-\left(R_{\text {OWTS }}+R_{\text {Bjork }}\right)}\right)
$$


where $C_{\text {Borst }}, C_{\text {Torp }}$ and $C_{\text {Bjorka }}($ pathogens $/ L$ ) were the pathogen concentrations in the tributaries; $R_{O W T S}$ (no unit) was the $\log _{10}$ reduction in the OWTSs; and $R_{\text {Borst }}, R_{\text {Torp }}$ and $R_{\text {Bjork }}$ (no unit) were the $\log _{10}$ reduction due to transport in Lake Vomb from the tributary to the raw water intake. Reduction in the catchment from OWTS discharge until entering Lake Vomb was conservatively assumed to be negligible due to the longevity of pathogens and the rapid transport (Sundahl et al. 2008) in the catchment.

Hydrodynamic modelling was performed to simulate the fate and transport of pathogens from the point of entering Lake Vomb from the three tributaries to the raw water intake. Due to the linearity of the hydrodynamic model, a constant load was used to estimate the pathogen reduction. Decay of the pathogens was calculated as:

$$
C_{t}=\mathrm{C}_{0} \cdot e^{-w t}
$$

where $C_{t}($ pathogens $/ L)$ was the concentration at $t ; C_{0}($ pathogens $/ L)$ was the initial concentration; $w(1 /$ day) was the decay rate; and $t$ was the time step. The $w$ value was set to 0.23 for Campylobacter and 0.03 for Cryptosporidium and norovirus, based on the estimates of half-life of pathogens in environment. For Campylobacter, the median half-life was estimated from various literature sources (Catalao Dionisio et al. 2000, Cook and Bolster 2007, Hendricks 1971, McGee et al. 2002, Medema et al. 1997, Nasser et al. 2003, Ottosson and Stenström 2003, Rhodes and Kator 1988, Terzieva and McFeters 1991). For Cryptosporidium and norovirus the same half-life was used, estimated as the median half-life given in literature (Medema et al. 1997, Nasser et al. 2003, Ottosson and Stenström 2003). Cryptosporidium was also reduced due to settling in the lake. In the MIKE 3 FM, the settling velocity for Cryptosporidium was specified as $0.03 \mathrm{~m} /$ day, which is the settling velocity previously suggested for free oocysts (Medema et al. 1998). It was conservatively assumed that Cryptosporidium oocysts released into the lake were not attached to particles. 
Comparing the input pathogen concentration at each tributary with the resulting pathogen concentration at the raw water intake, the daily $\log _{10}$ reduction due to transport in the lake was calculated. Three year time-series of daily $\log _{10}$ reductions were used to estimate the variability in the daily $\log _{10}$ reduction for the three different transport paths. The estimated $\log _{10}$ reductions for each tributary are presented in Table 1.

The pathogen concentration in drinking water $\left(C_{D W}\right.$, pathogens $\left./ L\right)$ was calculated as:

$$
C_{D W}=C_{R W} \cdot 10^{-\left(R_{U Z}+R_{S Z}+R_{C T}+R_{U V}\right)}
$$

where $R_{U Z}$ (no unit) was the total $\log _{10}$ reduction in the unsaturated zone; $R_{S Z}$ (no unit) was the total $\log _{10}$ reduction in the saturated zone; $R_{C T}$ (no unit) was the $\log _{10}$ reduction by the conventional treatment at the DWTP; and $R_{U V}$ (no unit) was the total $\log _{10}$ reduction by the UV-disinfection. The chlorination step was assumed not to contribute to the microbial removal because of a small dose and that chloramine was used as disinfection agent ${ }^{1}$.

The $\log _{10}$ reduction in the unsaturated zone $\left(R_{U Z}\right.$, no unit) was calculated as:

$$
R_{U Z}=R_{U Z / m} \cdot D p_{U Z}
$$

where $R_{U Z / m}\left(\log _{10} / m\right)$ was the $\log _{10}$ reduction per meter, and $D p_{U Z}(m)$ was the depth of the unsaturated zone.

For Campylobacter and Cryptosporidium, the $\log _{10}$ reduction in the saturated zone $\left(R_{S Z}, n o\right.$ unit) was calculated as:

$$
R_{\mathrm{SZ}}=R_{\mathrm{SZ} / m} \cdot L_{\mathrm{SZ}}
$$

where $R_{S Z / m}\left(\log _{10} / m\right)$ was the $\log _{10}$ reduction per meter in saturated zone, and $L_{S Z}(m)$ was the length of the saturated zone. For norovirus, the $\log _{10}$ reduction in saturated zone $\left(R_{S Z}\right.$, no

\footnotetext{
${ }^{1}$ Personal communication the Southern Sweden Water Supply (Sydvatten).
} 
256

257

258

259

260

261

262

263

264

265

266

267

268

269

270

271

272

273

274

275

276

277

unit) was estimated using a groundwater transport model (Åström et al. 2016, Schijven et al. 2006).

The estimated $\log _{10}$ reductions in conventional treatment $\left(R_{C T}\right)$ are presented in Table 1.

The $\log _{10}$ reduction by the UV-disinfection $\left(R_{U V}\right.$, no unit) was described as a first order disinfection model and calculated as:

$$
R_{U}=-x \cdot f-b
$$

where $x\left(\mathrm{~cm}^{2} / \mathrm{mJ}\right)$ was an inactivation constant; $b$ (no unit) was the interception of the fluence axis; and $f\left(\mathrm{~mJ} / \mathrm{cm}^{2}\right)$ was fluence.

\subsubsection{Dose-response}

To estimate the health effects in the form of infections due to the pathogens in the drinking water, the pathogen daily dose $(D$, pathogens/day) was calculated as.

$$
D=C_{D W} \cdot W
$$

where WI $(L)$ was the daily ingested volume of drinking water per capita in Sweden (Westrell et al. 2006). All three reference pathogens were assigned the Exact Beta-Poisson dose-

response function. An Exact Beta-Poisson function can be represented by an exponential function with a beta distribution in the exponent (Equation 9); this approach has been reported to be representative in infection studies (Teunis et al. 2005, Teunis et al. 2002, Teunis et al. 2008).

$$
P_{i n f}=1-e^{-m \cdot D}
$$

where $P_{\text {inf }}$ (probability) was the daily probability of infection for each pathogen; $m$ (no unit) was the infectivity; and $D$ was the simulated daily pathogen dose that was ingested.

The annual probability of infection ( $P_{\text {annual }}$, probability) was calculated as: 


$$
P_{\text {anпиаl }}=1-\prod_{1}^{365}\left(1-P_{\text {inf }}\right)
$$

A bootstrap technique was used to sample 365 random $P_{\text {inf }}$ values for each iteration calculating the annual probability (Equation 10). This is necessary since the daily probability of infection is not constant for one year. $P_{\text {annual }}$ was used to calculate the QALYs lost $(Q A L Y s$, QALYs lost per person per year):

$$
Q A L Y S=P_{\text {ammual }} \cdot Q
$$

where $Q(Q A L Y$ s/infection $)$ was the amount of QALYs reported per infection for each pathogen. All infections were assumed to result in QALYs. $P_{\text {annual }}$ was also used to calculate DALYs per person as suggested by the WHO (Havelaar et al. 2000, Kemmeren et al. 2006, WHO 2001). The Swedish population age structure of 2010 from the European database (EU 2010) was used to characterise the drinking water consumer population.

Three separate probabilities of infection ${ }^{2}$ for the three pathogens were summarised into the total probability of infection $\left(P_{\text {annual_tot }}\right.$, probability) calculated as:

$$
P_{\text {annual_tot }}=1-\left(1-P_{\text {annual_noro }}\right) \cdot\left(1-P_{\text {annual_camp }}\right) \cdot\left(1-P_{\text {annual_cryp }}\right)
$$

where $P_{\text {annual_noro }}, P_{\text {annual_camp }}$ and $P_{\text {annual_cryp }}($ probabilities) were the annual probabilities of infection due to norovirus, Campylobacter and Cryptosporidium respectively.

\subsection{Cost-benefit analysis (CBA)}

A CBA was performed to compare the economic negative effects (costs) with the positive effects (benefits) for each alternative. All inputs for the CBA are presented in Table 2; input distributions represent both epistemic uncertainties and aleatory uncertainties. To enable a

\footnotetext{
${ }^{2}$ This implies that the different events are independent. Since pathogens often originate from faecal contamination, one could argue that the presence of one pathogen could increase the probability for the presence of another, resulting in a positive correlation that has not been accounted for.
} 
comparison of the alternatives' societal profitability, the net present value $(N P V)$ was calculated and a distributional analysis was performed for each alternative. The $N P V(S E K)$ was calculated as:

$$
N P V=\sum_{t=0}^{T} \frac{\left(B_{t}\right)}{(1+r)^{t}}-\sum_{t=0}^{T} \frac{\left(C_{t}\right)}{(1+r)^{t}}
$$

where $B(S E K)$ and $C(S E K)$ were the benefits and costs for each year $t$ during the time horizon $T$ (years); $r(\%)$ was the discount rate used. $T$ was set to 100 years, representing the expected life-time of the mitigation alternatives.

The procedure used in this study for taking into account the project-specific costs and benefits, as well as externalities, follows the basic concept of CBA given by e.g. Boardman et al. (2011), among others. The total annual benefits $\left(B_{t o t}, S E K\right)$ were calculated as:

$$
B_{\text {tot }}=B_{\text {health }}+B_{\text {enwiromental }}+B_{\text {other }}
$$

where $B_{\text {health }}(S E K)$ were the benefits estimated from reduced negative health effects to drinking water consumers; $B_{\text {environmental }}(S E K)$ were the benefits from reduced nitrogen $(\mathrm{N})$ and phosphorous $(\mathrm{P})$ discharge to recipient water bodies due to increased treatment efficiency; and $B_{\text {other }}(S E K)$ were other benefits.

Health benefits $\left(B_{\text {health }}\right)$ for A1-A4 were calculated as:

$$
B_{\text {health }}=\triangle Q A L Y s \cdot Q A L Y_{B} \cdot D W C_{t}
$$

where $\triangle Q A L Y S(Q A L Y s)$ were the QALYs gained per person in year $t$ in relation to the reference alternative ( $Q A L Y s A$-ref) for each mitigation alternative; $Q A L Y_{\mathrm{B}}(S E K / Q A L Y)$ was the monetary value per QALY; and DWC (persons) was the number of drinking water consumers in year $t$. The value of a $Q A L Y$ is further discussed in the sensitivity analysis, Section 3.4 . 
320 Environmental benefits for A1-A3 (in A4, environmental benefits were assumed to be zero) were calculated as:

$$
B_{\text {Enirommental }}=N \cdot S E K_{N}+P h p \cdot S E K_{P}
$$

where $N(\mathrm{~kg})$ was the increased nitrogen removal; $S E K_{N}(S E K / \mathrm{kg})$ was the monetary value per was the monetary value per $\mathrm{kg}$ phosphorous removed.

326 Other benefits $\left(B_{\text {other }}\right)$ were not monetised using quantitative measures. However, to illustrate

327 the importance of these benefits, an analysis of how large they need to be to produce a

328 positive $N P V$ was conducted within the sensitivity analysis.

329 Investment costs were added to the first year of the CBA. For A1-A3, the investment costs $330 \quad\left(C_{\text {Investments }}, S E K\right)$ were calculated as:

$$
C_{\text {Investments }}=C_{W W T P}+C_{\text {Pump }} \cdot \text { Pumps }+C_{\text {Con_WWIP }} \cdot \text { OWTSs }+C_{\text {Pipe }} \cdot W P
$$
per OWTS; OWTSS (\#) was the number of OWTS connected; $C_{\text {Pipe }}(S E K / m)$ was the cost per pipe meter; and $W P(m)$ was the pipe length for each alternative. 
Table 2 Inputs for the cost-benefit analysis.

\begin{tabular}{|c|c|c|c|c|}
\hline Input & Unit & Abbr. & Distr. $^{\mathrm{m}}$ & Parameters \\
\hline \multicolumn{5}{|c|}{ General input } \\
\hline Time horizon & $\mathrm{y}$ & $T$ & $\mathrm{PV}$ & 100 \\
\hline Discount rate & $\%$ & $r$ & PV & High value $=3.5$, Low value $=1 \%$ \\
\hline OWTSs connected & $\#$ & OWTSs & PV & $\mathrm{A} 1=621, \mathrm{~A} 2=1,240, \mathrm{~A} 3=1864, \mathrm{~A} 4=0$ \\
\hline Persons per OWTS & \# & $P_{O W T S}$ & PV & 2.5 (as reported in Table 1$)$ \\
\hline Wastewater pipe length (A1) ${ }^{\mathrm{a}}$ & $\mathrm{m}$ & $W P_{A l}$ & $\mathrm{~T}$ & Min $=8 * 10^{3}$, Mode $=8.8 * 10^{3}, \operatorname{Max}=9.5 * 10^{3}$ \\
\hline Wastewater pipe length (A2) ${ }^{a}$ & $\mathrm{~m}$ & $W P_{A 2}$ & $\mathrm{~T}$ & $\operatorname{Min}=1.4 * 10^{4}$, Mode $=1.5^{*} 10^{4}, \operatorname{Max}=1.6^{*} 10^{4}$ \\
\hline Wastewater pipe length (A3) ${ }^{a}$ & $\mathrm{~m}$ & $W P_{A 3}$ & $\mathrm{~T}$ & $\operatorname{Min}=2.8 * 10^{4}, \operatorname{Mode}=3 * 10^{4}, \operatorname{Max}=3.2 * 10^{4}$ \\
\hline Drinking water consumers & \# & $D W C$ & PV & 330,000 \\
\hline Population increase & \#/year & $P I$ & PV & 2300 \\
\hline \multicolumn{5}{|c|}{ Investment cost } \\
\hline Number of pumps required ${ }^{b}$ & Pumps & Pumps & PV & $\mathrm{A} 1=1, \mathrm{~A} 2=10, \mathrm{~A} 3=20, \mathrm{~A} 4=0$ \\
\hline Cost for expanding WWTP (A1) ${ }^{a}$ & SEK & $C_{W W T P A l}$ & $\mathrm{LN}$ & $\mathrm{P} 05=5 * 10^{6}, \mathrm{P} 95=6 * 10^{6}$, Location $=0$ \\
\hline Cost for expanding WWTP (A2) ${ }^{a}$ & SEK & $C_{W W T P A A 2}^{W W T A 1}$ & $\mathrm{LN}$ & $\mathrm{P} 05=10^{*} 10^{6}, \mathrm{P} 95=11 * 10^{6}$, Location $=0$ \\
\hline Cost for expanding WWTP (A3) ${ }^{a}$ & SEK & $C_{W W T P A A 3}$ & $\mathrm{LN}$ & $\mathrm{P} 05=1.6 * 10^{7}, \mathrm{P} 95=1.7 * 10^{7}$, Location $=0$ \\
\hline Cost per pump installation ${ }^{b}$ & SEK & $C_{\text {Pump }}$ & $\mathrm{N}$ & $\mathrm{P} 05=4.5 * 10^{4}, \mathrm{P} 95=5.5 * 10^{4}$, Location $=0$ \\
\hline Cost per meter pipe ${ }^{b}$ & $\mathrm{SEK} / \mathrm{m}$ & $C_{\text {Pipe }}$ & $\mathrm{LN}$ & $\mathrm{P} 05=3,150, \mathrm{P} 95=3,850$, Location $=0$ \\
\hline Cost for installing UV treatm. ${ }^{c}$ & SEK & $C_{U V}$ & $\mathrm{LN}$ & $\mathrm{P} 05=5.3 * 10^{7}, \mathrm{P} 95=5.7 * 10^{7}$, Location $=0$ \\
\hline Cost for connecting to WWTP ${ }^{\mathrm{i}}$ & SEK/OWTS & $C_{\text {Con } W W T P}$ & PV & $1.29 * 10^{5}$ \\
\hline \multicolumn{5}{|c|}{ Annual costs } \\
\hline Water use per person per day ${ }^{\mathrm{e}}$ & $\mathrm{m}^{3} / \mathrm{p} / \mathrm{y}$ & $W U$ & $\mathrm{PV}$ & 58.4 \\
\hline Cost per $\mathrm{m}^{3}$ water used ${ }^{\mathrm{f}}$ & $\mathrm{SEK} / \mathrm{m}^{3}$ & $C_{\text {Water }}$ & PV & 26.36 \\
\hline Cost for water services ${ }^{f}$ & SEK/y/Con & $C_{\text {Con_Year }}$ & PV & 2,792 \\
\hline Cost for OWTS maintenance ${ }^{\mathrm{g}}$ & $\mathrm{SEK} / \mathrm{y}$ & $C_{\text {Sludge }}$ & PV & 1,118 \\
\hline Lifetime of an OWTS ${ }^{\text {h }}$ & $\mathrm{y}$ & $O W T S_{\text {Life }}$ & PV & 25 \\
\hline Cost for re-investing in OWTS ${ }^{b}$ & SEK & $C_{\text {OWTS RI }}$ & PV & $1.3 * 10^{5}$ \\
\hline Cost for UV treatm. maintenance ${ }^{\mathrm{d}}$ & $\mathrm{SEK} / \mathrm{y}$ & $C_{\text {UVmaint. }}$ & $\mathrm{LN}$ & $\mathrm{P} 05=4.2 * 10^{5}, \mathrm{P} 95=4.4 * 10^{5}$, Location $=0$ \\
\hline \multicolumn{5}{|c|}{ Benefits } \\
\hline Benefit/QALY avoided (High) ${ }^{j}$ & SEK/QALY & $Q A L Y_{B_{-} H}$ & $\mathrm{PV}$ & $1.22 * 10^{6}$ \\
\hline Benefit/QALY avoided (Low) ${ }^{\mathrm{j}}$ & SEK/QALY & $Q A L Y_{B_{-} L}$ & PV & $7 * 10^{5}$ \\
\hline Benefit per $\mathrm{kg} \mathrm{N}$ avoided ${ }^{\mathrm{k}}$ & $\mathrm{SEK} / \mathrm{N}$ & $S E K_{N}$ & PV & 22.91 \\
\hline Benefit per kg P avoided ${ }^{\mathrm{k}}$ & $\mathrm{SEK} / \mathrm{N}$ & $S E K_{P}$ & PV & 53.06 \\
\hline Increase, $\mathrm{N}$ removal/year $(\mathrm{A} 1)^{1}$ & $\mathrm{~kg} \mathrm{~N} / \mathrm{y}$ & $N_{A 1}$ & $\mathrm{~T}$ & Min $=3,550$, Mode $=4,000, \operatorname{Max}=4,450$ \\
\hline Increase, $\mathrm{N}$ removal/year $(\mathrm{A} 2)^{1}$ & $\mathrm{~kg} \mathrm{~N} / \mathrm{y}$ & $N_{A 2}$ & $\mathrm{~T}$ & Min $=7,100$, Mode $=8,000, \operatorname{Max}=7,900$ \\
\hline Increase, $\mathrm{N}$ removal/year $(\mathrm{A} 3)^{1}$ & $\mathrm{~kg} \mathrm{~N} / \mathrm{y}$ & $N_{A 3}$ & $\mathrm{~T}$ & Min $=10,700$, Mode $=12,000, \operatorname{Max}=13,300$ \\
\hline Increase $\mathrm{P}$ removal/year $(\mathrm{A} 1)^{1}$ & $\mathrm{~kg} \mathrm{P} / \mathrm{y}$ & $P h p_{A I}$ & $\mathrm{~T}$ & Min $=580$, Mode $=650$, Max $=720$ \\
\hline Increase $\mathrm{P}$ removal/year $(\mathrm{A} 2)^{1}$ & $\mathrm{~kg} \mathrm{P} / \mathrm{y}$ & $P h p_{A 2}$ & $\mathrm{~T}$ & Min $=1,160$, Mode $=1,300, \operatorname{Max}=1,440$ \\
\hline Increase $\mathrm{P}$ removal/year $(\mathrm{A} 3)^{1}$ & $\mathrm{~kg} \mathrm{P} / \mathrm{y}$ & $P h p_{A 3}$ & $\mathrm{~T}$ & Min $=1,750$, Mode $=2,000, \operatorname{Max}=2,150$ \\
\hline
\end{tabular}

a) Total wastewater pipe length and cost for expanding the municipal WWTP for each alternative was derived from personal communication with P. Fröjd at Sjöbo municipality and by using expert judgements.

b) Cost per pump, amount of pumps and the pipe cost per meter were based on Swedish literature (Kärrman et al. 2012).

c) Cost for installing UV-treatment was based on personal communication with B.M. Pott at Southern Sweden Water Supply (Sydvatten)

d) Based on the cost per litre for medium sized drinking water treatment plants (Cotton et al. 2001).

e) Åström and Johansson (2015)

f) Since stormwater is not included, the fee for connecting OWTS to the municipal WWTP was reduced (Sjöbo Municipality 2016b).

g) Sludge removal cost (968 SEK/year) (Sjöbo Municipality 2016a) and electricity cost (150 SEK/year) (expert judgement).

h) Wastewater guide (2016)

i) Connection fee (101,450 SEK) (Sjöbo Municipality 2016b), application fee (2,550 SEK) (Sjöbo Municipality 2016c), and excavation and plumbing on own property (25,000 SEK) (expert judgement).

j) Svensson et al. (2015)

k) SEPA (2008a)

1) Based on: $41 \%$ non-functioning (zero reduction) OWTSs (SEPA 2004); triangular distributions representing the nitrogen $($ Min=20, Mode=30, Max=40) and phosphorous (Min=60, Mode=70, Max=80) percentage removal in OWTSs (SEPA 2015); point values estimating the nitrogen (70) (SEPA 2017) and phosphorous (96) (SEPA 2013) percentage removal in WWTP. Triangular distributions were derived using MC simulations.

m) $\mathrm{PV}=$ point value, $\mathrm{T}=$ triangular distribution, $\mathrm{LN}=\mathrm{Log}$ Normal distribution, N=Normal distribution 
Annual costs $\left(\triangle C_{\text {Annual }}, S E K\right)$ for A1-A3 when connected to the municipal WWTP in relation to having an OWTS were calculated as:

$$
\Delta C_{\text {Annual }}=C_{\text {Annual_wwTS }}-C_{\text {Annual_owTS }}
$$

where $C_{\text {Annual_WWTP }}(S E K)$ was the annual cost per property when connected to the municipal WWTP; and $C_{\text {Annual_oWTS }}(S E K)$ was the annual cost per property when having an OWTS.

The $C_{\text {Annual_WWTP }}$ was calculated as:

$$
C_{\text {Annual_WWIP }}=C_{\text {Water }} \cdot W U \cdot P_{\text {OWIS }} \cdot \text { OWISS }+C_{\text {Con_Year }} \cdot \text { OWTSS }
$$

where $C_{\text {Water }}\left(S E K / \mathrm{m}^{3}\right)$ was the cost for water use; $W U\left(\mathrm{~m}^{3} / \mathrm{p} /\right.$ year $)$ was the water use per person and year; $P_{\text {OWTS }}$ (persons) was the number of persons per OWTS; OWTSs (\#) was the number of OWTSs connected to the WWTP; and $C_{\text {Con_Year }}($ SEK/year/OWTS) was the annual connection fee per OWTS per year.

The $C_{\text {Annual_owTS }}$ was calculated as:

$$
C_{\text {Annual_oWTS }}=C_{\text {Sludge }} \cdot \text { OWTSs }+\frac{C_{\text {Reinv }} \cdot \text { OWTSS }}{O W T S_{\text {Life }}}
$$

where $C_{\text {Sludge }}(S E K / O W T S)$ was the annual cost for sludge removal per OWTS per year; $C_{\text {Reinv }}$ (SEK) was the cost for re-investing in a new OWTS; and $O W T S_{\text {Life }}$ (years) was the expected life time of an OWTS.

For A4, the investment cost was the installation of UV treatment $\left(C_{U V}, S E K\right)$, and the annual cost was the maintenance of the UV treatment $\left(C_{U V m a i n t}, S E K\right)$.

A distributional analysis was performed by assigning costs and benefits to private OWTS owners, drinking water consumers, or inhabitants/visitors of the catchment of Lake Vomb. 


\subsection{Uncertainty and sensitivity analysis}

To acknowledge epistemic and aleatory uncertainties, MC simulations were used in the QMRA and the CBA calculations. The model was divided into the following compartments: source characterisation; water quality modelling in the DWTP; dose-response in the QMRA; and the CBA. An adaptation of the local sensitivity analysis, which investigates the change in output by varying one input variable at a time, keeping all other input variables constant, as suggested by Schijven et al. (2013), was used. For the compartments with monotonic behaviour i.e. source characterisation, water quality modelling in the DWTP, and the CBA, the Spearman's rank correlation analysis was used (Mokhtari and Frey 2005). For the compartment with non-monotonic behaviour, i.e. dose-response in QMRA, scatter plots were used (Frey and Patil 2002). All results from the uncertainty and sensitivity analysis are reported in the supplementary material.

For investigating the uncertainties not suitable to model using probability distributions, scenarios were defined. Scenarios were used for the different values of a QALY, discount rate, and the proportion of OWTSs contribution to the total pathogen load. The low and high values of a QALY were assumed to be 700,000 and 1,220,000 SEK based on the government implied willingness to pay for a QALY (Svensson et al. 2015). For the discount rate, two scenarios were used: $1 \%$ or $3.5 \%$. The Swedish Transport Administration recommends 3.5 $\%$ for infrastructure projects in the traffic sector (STA 2016); this value is commonly used in other sectors as well. Since the time horizon was long and decisions affect several future generations, a low discount rate was also used. The pathogen load to Lake Vomb from OWTSs ( $L_{\text {OWTS }}$, pathogens/day) was calculated as:

$$
L_{\text {OWIS }}=C_{\text {Tributary }} \cdot F_{\text {Tributary }}
$$


The total pathogen load ( $L_{\text {total }}$, pathogens/day) originates from many sources (e.g. WWTP, fertilisation using manure, grazing animals, wild animals) and was illustrated as:

$$
L_{\text {total }}=L_{\text {OWTS }}+L_{\text {other }}
$$

where $L_{\text {other }}$ (pathogen/day) was the load from all other pathogen sources. Since the OWTSs load to Lake Vomb in relation to the total pathogen load was unknown, two scenarios $\left(L_{O W T S}\right.$ $=75 \%$ and $L_{O W T S}=50 \%$ of $\left.L_{\text {total }}\right)$ were investigated.

To estimate in what range the non-monetised benefits in A1-A3 would have to be in order to render a positive $N P V$, a calculation of non-monetised benefits to reach break-even $(N P V \geq 0)$ was performed.

\subsection{Software}

For the source characterisation and CBA calculations, the MC simulations were performed using Microsoft Excel, @RISK version 7.5.1. For the drinking water treatment performance, virus groundwater transport model and the dose-response relationship, the MC simulations were performed using Analytica release 4.1.6.30. For the hydrodynamic modelling, the model for Lake Vomb was developed using MIKE 3 FM (MIKE Powered by DHI), which is a deterministic three-dimensional numerical model that solves the incompressible Reynolds averaged Navier-Stokes equations invoking the assumptions of Boussinesq and hydrostatic pressure (DHI 2011). The period 2005-2007 was simulated using the observed hydrometeorological data.

Uncertainties were propagated between the different model compartments to calculate the probability distributions of the final results of the CBA. Using 10,000 MC iterations, the resulting probability distribution of the output of one model compartment was then used as an input in the next model compartment. The propagation of uncertainties and the combination of methods are illustrated in Figure 3. 


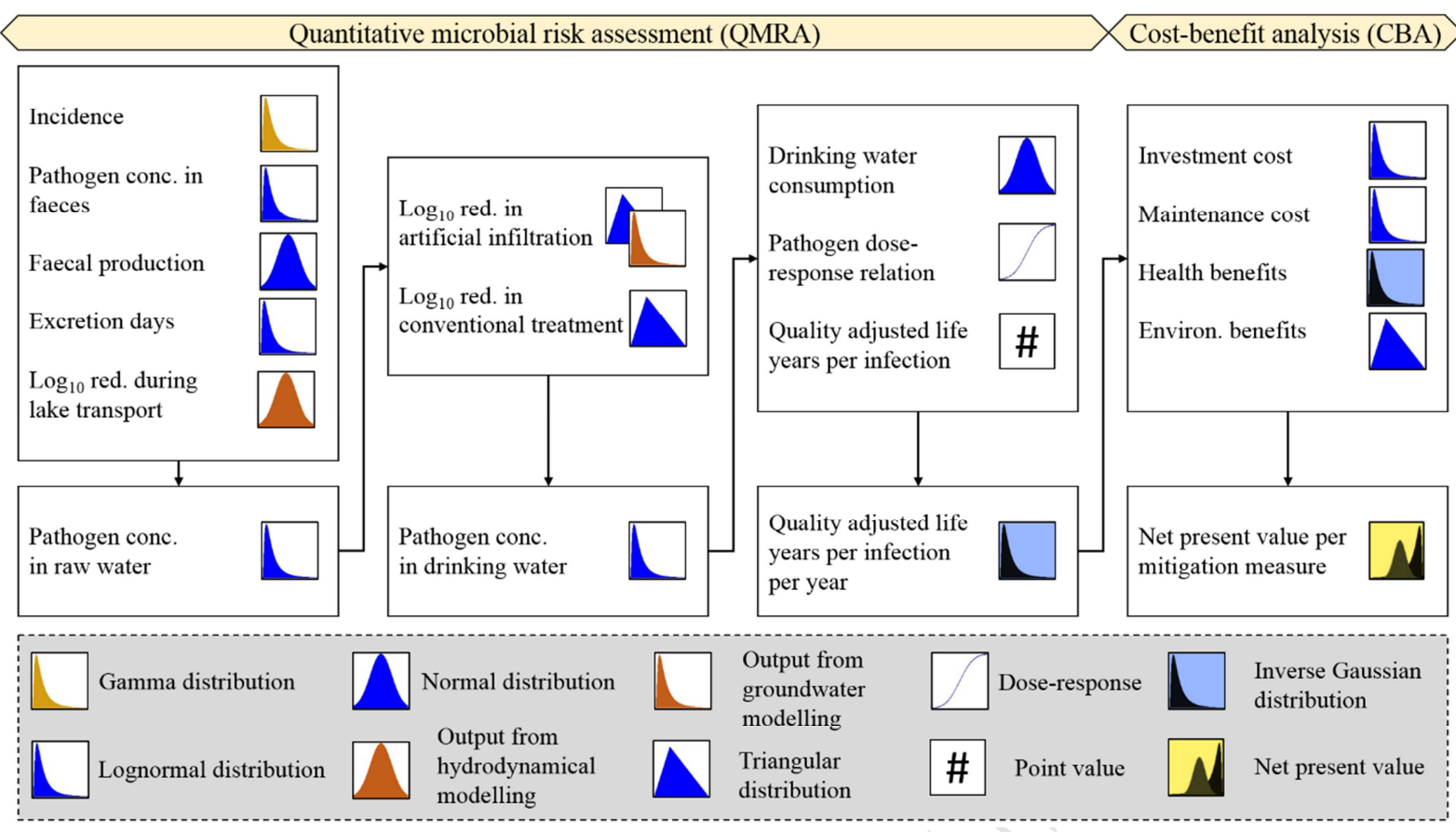

Figure 3 Schematic illustration of how the different methods are combined in the model.

\section{Results}

All results, unless stated otherwise, are from the scenario assuming that OWTSs are contributing $75 \%$ of the total pathogen load to Lake Vomb. The complete results from the source characterisation (Table S1), dose-response (Table S2), CBA (Table S3), and uncertainty and sensitivity analysis (Tables S4-S8, Figures S1-S5) are presented in the supplementary material.

\subsection{Cost-benefit analysis}

437 The costs, benefits and $N P V$ for the scenario with a high value $(1,220,000$ SEK) of a QALY

438 and a discount rate of $3.5 \%$ are presented (Figure 4 ) for the $5^{\text {th }}, 50^{\text {th }}$, and $95^{\text {th }}$ percentiles. 
a)

\section{Costs}

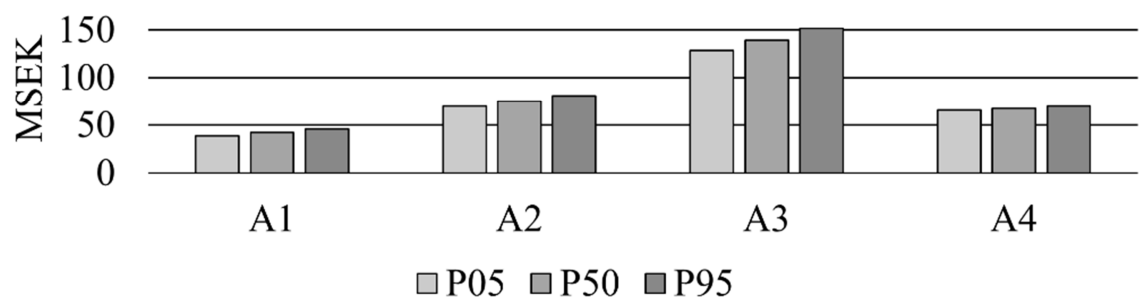

b)

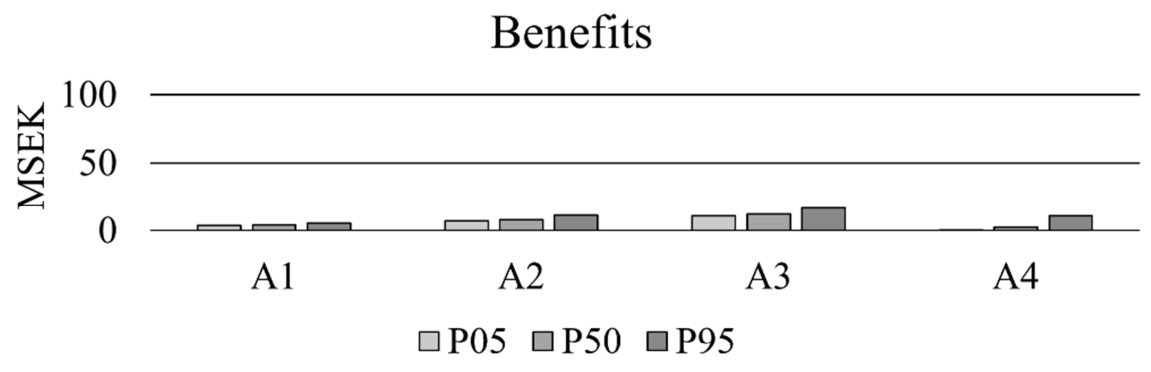

c)

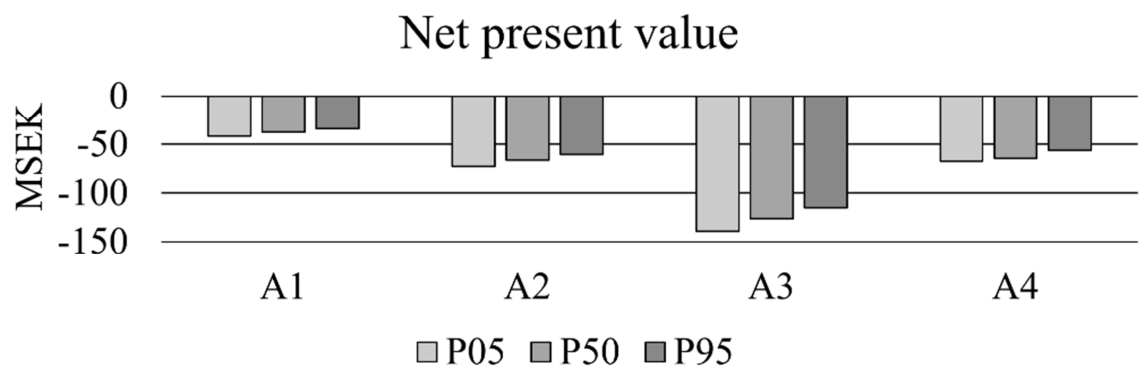

$440 \quad$ Figure 4. The costs (a), benefits $(b)$ and NPV (c) for the scenario with the high value of a

$441 Q A L Y\left(1,220,000\right.$ SEK) and the discount rate of $3.5 \%$ are presented for the $5^{\text {th }}, 50^{\text {th }}$, and $95^{\text {th }}$

442 percentiles in million SEK (MSEK).

443 For A1-A3, the costs would be solely taken by the owner of the OWTS that will be connected

444 to the WWTP (installation of pipes on their own property and a connection fee). For A4, the

445 costs would be solely taken by the drinking water producers initially and eventually by the

446 drinking water consumers through a higher drinking water fee. 
The benefits were distributed between the drinking water consumers (health benefits) and the inhabitants and visitors of the catchment area of Lake Vomb (environmental benefits). For A1-A3, the drinking water consumers received 11 or $18 \%$ and the inhabitants and visitors received 89 or $82 \%$ of the benefits, using a low or high valuation of a QALY, respectively. For A4, the benefits were solely attributed to the drinking water consumers.

\subsection{Uncertainty and sensitivity analysis}

For A1-A3 using $3.5 \%$ discount rate, the $N P V$ sensitivity to the inputs in the CBA were (top three in descending order): cost per pipe meter $\left(C_{\text {Pipe }}\right)$, wastewater pipe length $(W P)$, and $\triangle Q A L Y s$ (A1-A3). For A4 using $3.5 \%$ discount rate, the NPV sensitivity to the inputs in the CBA were (top three in descending order): $\triangle Q A L Y s$ (A4), cost for installation of UV treatment $\left(C_{U V}\right)$ and cost for maintenance of UV treatment $\left(C_{U V m a i n t}\right)$.

The concentration of norovirus in raw water $\left(C_{R W_{-} \text {Noro }}\right)$ was the most sensitive to the following inputs (top three in descending order): concentration in faeces $(C)$, incidence $\left(I_{N o r o}\right)$, and days excreting $\left(D_{\text {Noro }}\right)$. The concentration of Campylobacter in raw water $\left(C_{R W_{-} C a m p}\right)$ was the most sensitive to the following inputs (top three in descending order): concentration in faeces $(C)$, $\log _{10}$ reduction in Björkaån $\left(R_{\text {Bjork_Camp }}\right)$, and $\log _{10}$ reduction in Torpsbäcken $\left(R_{\text {Torp_Camp }}\right)$. The concentration of Cryptosporidium in raw water $\left(C_{R W_{-} C r y p}\right)$ was the most sensitive to the following inputs (top three in descending order): concentration in faeces $(C)$, days excreting $\left(D_{\text {Cryp }}\right)$, and incidence $\left(I_{\text {Cryp }}\right)$.

The concentration of norovirus in drinking water $\left(C_{D W_{-} \text {Noro }}\right)$ was the most sensitive to the foellowing inputs (top three in descending order): $\log _{10}$ reduction in saturated zone $\left(R_{S Z_{-} \text {noro }}\right)$, raw water concentration $\left(C_{R W \_N o r o}\right)$, and $\log _{10}$ reduction per meter in unsaturated zone $\left(R_{U Z / m_{-} \text {Noro }}\right)$. The concentrations of Campylobacter $\left(C_{D W_{-} \text {Camp }}\right)$ and Cryptosporidium $\left(C_{D W_{-} C r y p}\right)$ in drinking water were the most sensitive to the following inputs (top three in descending 
471 order): $\log _{10}$ reduction per meter in saturated zone $\left(R_{S Z_{-} \text {Camp }}\right.$ and $\left.R_{S Z_{-} \text {Crypp }}\right)$, saturated zone

472 vertical length $\left(L_{S Z}\right)$, and raw water concentration $\left(C_{R W_{-} C a m p}\right.$ and $\left.C_{R W_{-} C r y p}\right)$.

473 The dose-response relationship between the concentrations of pathogens in drinking water

$474\left(C_{D W}\right)$, infectivity $(m)$, drinking water consumption $(W I)$ and the probability of infection $\left(P_{\text {inf }}\right)$

475 was illustrated using scatter plots from the 10,000 MC simulations.

476 A scenario-based analysis was performed to analyse the effects on the final NPVs from

477 uncertainties regarding the QALY valuation, discount rate, and the OWTSs contribution to

478 the total pathogen load. The rank order of the $50^{\text {th }}$ percentiles for the $N P V(\mathrm{~A} 1>\mathrm{A} 4>\mathrm{A} 2>\mathrm{A} 3)$

479 does not change depending on the level of OWTSs contribution to the total pathogen load nor 480 the QALY valuation. However, with a low discount rate (1\%), the rank order changes to $481 \quad \mathrm{~A} 1>\mathrm{A} 2>\mathrm{A} 4>\mathrm{A} 3$.

482 Benefits that have not yet been monetised and included in the CBA that might alter the rank 483 order of $N P V$ for the alternatives were identified. For alternatives A1-A3, non-monetised 484 benefits are:

- positive health effects for humans from improved water quality for recreational activities in Lake Vomb;

- positive health effect for animals (both domestic and wild) from improved water quality in the catchment and in Lake Vomb;

- $\quad$ perceived value for private OWTS owners not being responsible for treating their wastewater;

- increased market value of the properties connected to the municipal water and wastewater system; OWTSs; 
- possibility to recycle nutrients when wastewater is treated at the WWTP;

- reduction of $\mathrm{CO}_{2}$ emission when sludge transportation trucks do not need to empty closed tanks and three compartment septic tanks;

- reduced traffic accidents and related risks since heavy traffic is reduced in the catchment area.

For alternative A4, non-monetised benefits are:

- less disinfection by-products due to lower dosage in chlorination;

- reduced handling and storage of chlorination chemicals.

For A1-A3, these additional benefits need to be 800-1200 SEK or 1800-2400 SEK per OWTS per year for $1 \%$ and $3.5 \%$ discount rate, respectively, to give a positive $N P V\left(50^{\text {th }}\right.$ percentile $)$. These ranges apply for both the high and low valuation of a QALY.

\section{Discussion}

The aim of this study was to present an approach for comprehensive decision analysis using CBA of microbial risk mitigation measures in DWSs, and including Lake Vomb as a case to illustrate the assumptions needed and the associated variabilities and uncertainties. Below we discuss the QMRA, the CBA, the uncertainties, and the overall applicability of the decision model.

\subsection{Quantitative microbial risk assessment}

\subsubsection{Source characterisation}

Pathogen concentration in faeces and the pathogen excretion duration are subject to large variability. In this study, it was assumed that the catchment was large enough to have pathogens present at all times, evenly distributed geographically. However, if a smaller catchment is to be described, it will be important to account for temporal and geographical 
variations of the pathogen prevalence. If persons are infected, there will be high pathogen concentrations in the OWTSs effluents, otherwise there will be no pathogens present. One way forward is to combine the data on incidence with binary probability density functions. This would capture the on/off characteristics of infections and enable the use of the decision model on smaller systems, even on a single OWTS.

To acknowledge the ambiguity (a factor of 100 between values) and the lack of information in the underreporting factor, it was assigned a point value and not included in the MC simulations. However, the factor for underreporting is uncertain, and further investigations on how to describe this input need to be conducted. The factor for underreporting is important, since increased underreporting results in a corresponding increase of the estimation of the pathogen concentration at the raw water intake.

The estimated pathogen load to Lake Vomb can be validated. The estimated concentrations of Cryptosporidium in the tributaries (0.36-1.4 oocysts/L) in this study are in agreement with the values reported by other studies, e.g. the mean of 0.62 oocysts/L in an Australian river (Swaffer et al. 2014). The estimated concentrations could also be validated by monitoring the local pathogen concentrations in the catchment; however, this is tedious and expensive.

Instead, based on the factor for underreporting and the incidence of norovirus (since it was the pathogen causing the main part of the loss of QALYs), we made an estimate of the annual infections in the drinking water consumer population, confirming that the waterborne infections only represented a small proportion of the total infections calculated from the incidence. Chosen values and associated probability distributions should be regarded as a possible, but not necessarily the optimal, representation of the pathogen source characteristics.

\subsubsection{Water quality modelling}

The $\log _{10}$ reduction during transport in Lake Vomb was estimated using hydrodynamic modelling encompassing several years of daily and sub-daily variation in 
543

544

545

546

547

548

549

550

551

552

553

554

555

556

557

558

559

560

561

562

563

564

565

566

567

hydrometeorological data. Looking at the best fit, a normal distribution was reasonable to use for describing the variability in pathogen reduction. Future development of water quality modelling within the decision model is to include probabilistic modelling. Probabilistic modelling will further facilitate risk-based modelling approaches, QMRA and holistic water resource management (Oliver et al. 2016).

The model describing the artificial groundwater recharge system was highly simplified. The pathogen reduction was based on a conceptual model describing the artificial groundwater infiltration as one system, when in reality there are many smaller sub-systems with complex flow and transport conditions between different infiltration ponds and abstraction wells. Nonetheless, the model is assumed to give a good understanding of the key processes affecting the level of reduction in the artificial infiltration.

Local investigations of the barrier efficiency at the DWTP would be preferred. Since it is not ethical to use active DWSs to directly test the reduction of pathogens, surrogate organisms can be used instead. It is also possible to use literature estimates. The $\log _{10}$ reduction of Cryptosporidium by the UV-disinfection was not allowed to be higher than $3 \log _{10}$, in order not to interpret results outside of the investigated range (Hijnen et al. 2006). Although this can be considered a low reduction given the efficiency of UV-disinfection towards Cryptosporidium, this approach is used in the QMRA-tool for drinking water producers in Sweden. However, the truncation in UV-treatment needs to be further investigated and thoroughly reviewed. Investigation of altering the UV-dose may also be of importance for future implementation of the decision model.

\subsubsection{Dose-response}

The estimated annual probability of infection $\left(P_{\text {annual }}\right)$ was slightly higher than the WHO guidelines in the current situation (A-ref, $50^{\text {th }}$ percentile), while the DALYs were under the threshold (A-ref, $5^{\text {th }}$ percentile), indicating that there is ambiguity whether the microbial risks 
568

569

570

571

572

573

574

575

576

577

578

579

580

581

582

583

584

585

586

587

588

589

590

591

592

were acceptable or not. The large uncertainty and variability described in input probability distributions should be taken under consideration when interpreting the results. To get below the WHO guideline for $P_{\text {annual }}$ looking at the $50^{\text {th }}$ percentile, A2, A3 and A4 are the possible options, while A1 almost reaches the threshold. It is only A4 that meets the guideline level with respect to the $95^{\text {th }}$ percentile. Even though no strict guideline level exists in Sweden, drinking water producers should be aware of the discrepancy between meeting the DALY or $P_{\text {annual }}$ WHO guideline. The same pathogen concentration in drinking water can meet one target and miss the other.

$P_{\text {anпиаl }}$ was calculated into to QALYs using standard unit values adopted from a study from the U.S (Batz et al. 2014). It may be argued that results from the U.S. are not representative for Swedish settings. Even so, to illustrate the methodology, it was assumed that the U.S. values would be useful. However, further development of the model could use more detailed health effect quantification and implement local studies for estimating the quantity of the health risk reduction in the risk mitigation alternatives. To monetise the health effects, there are other approaches which can be implemented into the model, e.g. information from previous events, quality of life investigations, etc.

\subsection{Cost-benefit analysis}

None of the mitigation alternative rendered a positive $N P V$. However, the $N P V$ results must be interpreted using a wider perspective in combination with other results from the CBA, such as distributional analysis and non-monetised benefits. From a socio-economic perspective, it is important to identify the alternative with the least negative $N P V(\mathrm{~A} 1)$. In a situation where decision makers are required to reduce the microbial risk, they will need to choose an alternative. Such a situation would occur e.g. if there is a guideline or risk level that needs to be achieved, such as the WHO recommendation of a maximum yearly probability of infection per person of $10^{-4}$ or a maximum DALY of $10^{-6}$ (WHO 2011). If looking at the $50^{\text {th }}$ percentile 
593

594

595

596

597

598

599

600

601

602

603

604

605

606

607

608

609

610

611

612

613

with $1 \%$ discount rate, both $\mathrm{A} 1$ and $\mathrm{A} 2$ resulted in higher NPVs than $\mathrm{A} 4$. Nevertheless, as noted above, only A4 would achieve the WHO recommendation of the $P_{\text {annual }}$ with a high degree of certainty (looking at the $95^{\text {th }}$ percentile).

When monetising health benefits, it is important to make sure that the underlying valuation study represents the relevant health effects. The monetisation of health benefits was based on a governmental implied willingness to pay for a QALY (Svensson et al. 2015). The values used were estimated from a societal perspective, i.e. the effects both within the health care sector (e.g. reduced medical and hospitalisation costs) and beyond the health care sector (e.g. reduced discomfort from being ill and loss of production) were accounted for.

When decision makers choose an alternative, they also accept the distribution between beneficiaries and payers associated with the decision. Even though the Kaldor-Hicks criterion $^{3}$ can be argued, the distribution of the costs and benefits will need to be communicated with stakeholders. Alternative A4 is the only alternative when the beneficiary and the payer are the same stakeholder. In decision making, distributional analysis can be of importance when applying the polluter pays principle.

\subsection{Uncertainty and sensitivity analysis}

The Spearman's rank correlation is inadequate (Ellouze et al. 2010) for measuring sensitivity when analysing complex relationships such as the dose-response relation in QMRA. We have used scatter plots to illustrate the relationships between drinking water pathogen

concentration, drinking water consumption and the infectivity. Future research needs to investigate more advanced sensitivity analysis methods (see e.g. Mokhtari and Frey 2005).

\footnotetext{
${ }^{3}$ The Kaldor-Hicks criterion, simply put, state that: beneficiaries can compensate those that pay or experience negative effects. However, the compensation only needs to be possible and not realized, since it is argued that if a decision is societally profitable, the costs and benefits will eventually even out with regard to different stakeholders.
} 
614 Since the total risk level in the drinking water system cannot be estimated, it was important to

615

616

617

618

619

620

621

622

623

624

625

626

627

628

629

630

631

632

633

634

635

636

637

investigate whether the results change if the OWTSs contribution to the total risk is altered.

Results showed that changing the OWTSs contribution to the total pathogen load did not change the ranking of the alternatives.

After scrutinising the CBA results, decision-makers need to consider benefits that were omitted from the monetised analysis. Even though the $N P V s$ were negative for the A1-A3 alternatives, all alternatives could render a positive $N P V$ (looking at the $50^{\text {th }}$ percentile) if these other benefits could be valued in the range of 800-2400 SEK per connected OWTS per year. The value of the benefits when using a $3.5 \%$ discount rate need to be approximately 1000 SEK higher than when using a $1 \%$ discount rate.

Some factors vary over time both within a year, e.g. incidence and water flow etc., and over longer time periods, e.g. population increase, climate change etc., to mention a few. The model included a population increase based on population projections for Sweden in general. However, the inter-yearly variations have not been included. For further development of the decision model, methods for including these temporal variations and uncertainties need to be developed.

\subsection{Risk-based decision model}

Depending on the type of decision and the local settings, other methods than presented in this paper can be more suitable to combine in the decision model. For decisions aiming at reaching a certain guideline or threshold value, a CEA may be preferred, instead of a CBA. CBA represents a strict anthropocentric and utilitarian context, only accounting for benefits attributed to human values (Hutton 2001). If decision makers want to include intrinsic values, they need to apply methods that can consider such values as well, such as multi-criteria decision analysis (see e.g. DCLG 2009). In such multi-criteria decision models, the decision 
638

639

640

641

642

643

644

645

646

647

648

649

650

651

652

653

654

655

656

657

658

659

660

661

support rendered from the CBA and the QMRA can be used as input for appropriate criteria.

To give some examples, the $N P V$ can provide information to the economic dimension,

distributional analysis and QALY assessment can provide input to the social dimension, and

water quality modelling can provide input to the environmental dimension in a sustainability assessment, see e.g. Rosén et al. (2015).

The focus of this study was to describe the methodology of comparing microbial risk

mitigation measures using CBA in combination with QMRA to estimate risk levels and the

effect of possible mitigation measures. Benefits, in terms of the health risk reduction obtained in each alternative were described in detail. Environmental benefits were included using a more simplified approach. However, including the environmental benefits illustrates a key element of the CBA, i.e. the possibility to include other benefits, apart from the target risk reduction. These additional benefits may be of substantial importance and heavily affect the final decision.

The decision model incorporates both aleatory and epistemic uncertainties in the input probability distributions. To further develop the model and to provide additional decision support, these uncertainties can be divided. This separation would also facilitate additional decision analyses, e.g. value of information analysis.

\section{Conclusions}

Results from the case study showed that the alternative to connect the smallest proportion $(25 \%)$ of on-site wastewater treatment systems to the wastewater treatment plant (A1) at Lake Vomb was the most societally beneficial. However, the only alternative that would reduce the annual probability of infection to meet the WHO guidelines with a high degree of certainty $\left(95^{\text {th }}\right.$ percentile) was installing UV-disinfection (A4). In relation to the development of the risk-based decision model, the following conclusions were drawn: 
- The developed decision model is flexible and can be tailored to different drinking water systems and different types of decision problems.

- To implement the decision model, a multitude of uncertainties and variabilities needs to be addressed. However, the model provides tools to include these variabilities and uncertainties in a structured manner.

- Through the process of performing the cost-benefit analysis, aspects important for decision making that may otherwise easily be overlooked or ignored are openly displayed and assessed.

- The combination of quantitative microbial risk assessment and cost-benefit analysis provides a novel decision model that creates transparent and holistic decision support tool for microbial risk mitigation.

- For improvement of the decision model, we suggest to further develop the valuation and monetisation of health effects and the propagation of variability and uncertainty between the included methods.

\section{Acknowledgement}

This research has been performed as part of the project Risk-Based Decision Support for Safe Drinking Water, financed by the Swedish Water and Wastewater Association (project 13102), and as part of DRICKS, a framework programme for drinking water research at the Chalmers University of Technology. The information provided by the local water utility (Southern Sweden Water Supply) and the municipality of Sjöbo was most appreciated. Input regarding the sensitivity analysis, provided from Tommy Norberg was highly appreciated. 
683

684

685

686

687

688

689

690

691

692

693

694

695

696

697

698

699

700

701

702

703

704

705

706

707

708

709

\section{References}

Assmuth, T., Simola, A., Pitkänen, T., Lyytimäki, J. and Huttula, T., 2016. Integrated frameworks for assessing and managing health risks in the context of managed aquifer recharge with river water. Integrated environmental assessment and management 12(1), 160-173.

Åström, J. and Johansson, V., 2015. GIS-based dispersion modelling of parasites in surface water sources, (In Swedish: GIS-baserad spridningsmodellering av parasiter i ytvattentäkter),

http://vav.griffel.net/filer/SVU-rapport_2015-07.pdf, Swedish Water and Wastewater Association, Stockholm.

Åström, J., Lindhe, A., Bergvall, M., Rosén, L. and Lång, L.-O., 2016. Microbial risk assessment of groundwater sources - development and implementation of a QMRA tool, (In Swedish:

Mikrobiologisk riskbedömning av grundvattentäkter - utveckling och tillämpning av ett QMRAverktyg), http://vav.griffel.net/filer/SVU-rapport_2016-19.pdf, Swedish Water and Wastewater Association, Stockholm.

Åström, J. and Pettersson, T.J.R., 2010. Technical efficiency of existing risk reduction options in surface water systems,

https://www.techneau.org/fileadmin/files/Publications/Publications/Deliverables/D4.3.3.pdf,

\section{TECHNEAU.}

Atmar, R.L., Opekun, A.R., Gilger, M.A., Estes, M.K., Crawford, S.E., Neill, F.H. and Graham, D.Y., 2008. Norwalk virus shedding after experimental human infection. Emerging infectious diseases 14(10), 1553.

Bartram, J., Coralles, L., Davison, A., Deere, D., Drury, D., Gordon, B., Howard, G., Rineholt, A. and Stevens, M., 2009. Water safety plan manual: step/by/step risk management for drinking-water suppliers, http://apps.who.int/iris/bitstream/10665/75141/1/9789241562638_eng.pdf, World Health Organization, Geneva.

Batz, M., Hoffmann, S. and Morris Jr, J.G., 2014. Disease-outcome trees, EQ-5D scores, and estimated annual losses of quality-adjusted life years (QALYs) for 14 foodborne pathogens in the United States. Foodborne pathogens and disease 11(5), 395-402. 
Beuken, R., Reinosos, M., Sturm, S., Kiefer, J., Bondelind, M., Åström, J., Lindhe, A., Rosén, L.,

711

712

713

714

715

Pettersson, T.J.R., Machenbach, I., Melin, E., Thorsen, T., Eikebrokk, B., Hokstad, P., Røstum, J., Niewersch, C., Kirchner, D., Kozisek, F., Gari Weyessa, D., Swartz, C. and Menaia, J., 2008. Identification and description of hazards for water supply systems - A catalogue of today's hazards and possible future hazards, updated version, https://www.techneau.org/fileadmin/files/Publications/Publications/Deliverables/D4.1.4.pdf, TECHNEAU.

Boardman, A.E., Greenberg, D.H., Vining, A.R. and Weimar, D.L., 2011. Cost-benefit analysis: concepts and practice, Prentice Hall, Upper Saddle River, N.J.

Cameron, J., Hunter, P., Jagals, P. and Pond, K., 2011. Valuing water, valuing livelihoods: guidance on social cost-benefit analysis of drinking-water interventions, with special reference to small community water supplies, IWA Publishing, World Health Organization, Geneva.

Catalao Dionisio, L.P., Joao, M., Soares Ferreiro, V., Leonor Fidalgo, M., García Rosado, M.E. and Borrego, J.J., 2000. Occurrence of Salmonella spp in estuarine and coastal waters of Portugal. Antonie van Leeuwenhoek 78(1), 99-106.

Cook, K.L. and Bolster, C.H., 2007. Survival of Campylobacter jejuni and Escherichia coli in groundwater during prolonged starvation at low temperatures. Journal of Applied Microbiology 103(3), 573-583.

Corso, P.S., Kramer, M.H., Blair, K.A., Addiss, D.G., Davis, J.P. and Haddix, A.C., 2003. Cost of illness in the 1993 waterborne cryptosporidium outbreak, Milwaukee, Wisconsin. Emerging infectious diseases 9(4), 426-432.

Cotton, C.A., Owen, D.M., Cline, G.C. and Brodeur, T.P., 2001. UV disinfection costs for inactivating Cryptosporidium. American Water Works Association, 93(6), 82-94.

DCLG, 2009. Multi-criteria Analysis: a Manual, https://www.gov.uk/government/uploads/system/uploads/attachment_data/file/7612/1132618.pdf, Department for Communities and Local Government, London. DHI, 2011. MIKE 21 \& MIKE 3 Flow Model FM Hydrodynamic and Transport Module — Scientific Documentation, Hørsholm. 
Dufour, A., Bartram, J., Bos, R. and Gannon, V., 2012. Animal waste, water quality and human health, IWA Publishing, London.

Ellouze, M., Gauchi, J.-P. and Augustin, J.-C., 2010. Global Sensitivity Analysis Applied to a Contamination Assessment Model of Listeria monocytogenes in Cold Smoked Salmon at Consumption. Risk Analysis 30(5), 841-852.

EU, 2010. Eurostat, http://ec.europa.eu/eurostat/, Union, E.

Ferguson, C.M., Charles, K. and Deere, D.A., 2009. Quantification of Microbial Sources in DrinkingWater Catchments. Critical Reviews in Environmental Science and Technology 39(1), 1-40.

Frey, C.H. and Patil, S.R., 2002. Identification and Review of Sensitivity Analysis Methods. Risk Analysis 22(3), 553-578.

Haas, C.N., Rose, J.B. and Gerba, C.P., 2014. Quantitative microbial risk assessment, Wiley, New Jersey.

Havelaar, A., de Wit, M. and van Koningsveld, R., 2000. Health burden of infections with thermophilic Campylobacter species in the Netherlands, 1990-1995,

http://www.rivm.nl/bibliotheek/rapporten/284550004.pdf, Netherlands National Institute of Public Health and the Environment, Rotterdam.

Havelaar, A. and Melse, J., 2003. Quantifying public health risk in the WHO Guidelines for drinkingwater quality: A burden of disease approach.

Hendricks, C.W., 1971. Increased Recovery Rate of Salmonellae from Stream Bottom Sediments Versus Surface Waters. Applied Microbiology 21(2), 379-380.

Hijnen, W.A.M., Beerendonk, E.F. and Medema, G.J., 2006. Inactivation credit of UV radiation for viruses, bacteria and protozoan (oo)cysts in water: A review. Water research 40(1), 3-22.

Hutton, G., 2001. Economic evaluation and priority setting in water and sanitation interventions, $\mathrm{Ch}$ 15 in Water quality: guidelines, standard and health, pp. 333-359, IWA Publishing, World Health Organization.

ISO, 2009. Risk management-Principles and guidelines, International Organization for Standardization, Geneva. 
765

766

767

768

769

770

771

772

773

774

775

776

777

778

779

780

781

782

783

784

785

786

787

788

789

790

Kärrman, E., Pettersson, F. and Erlandsson, Å., 2012. Costs for water and wastewater systems in transition areas - a guide book, (In Swedish Kostnader för VA i omvandlingsområden - en handledning), Swedish Water and Wastewater Association, Stockholm.

Keller, A.Z. and Wilson, H.C., 1992. Hazards to drinking water supplies, Springer.

Kemmeren, J.M., Mangen, M., Van Duynhoven, Y. and Havelaar, A., 2006. Priority setting of foodborne pathogens: disease burden and costs of selected enteric pathogens,

\section{http://www.rivm.nl/dsresource?objectid=258d5bf6-58d9-49ec-b268-}

2d0a0e5bb63b\&type=org\&disposition=inline, Netherlands National Institute of Public Health and the Environment, Bilthoven.

Larsson, C., Andersson, Y., Allestam, G., Lindqvist, A., Nenonen, N. and Bergstedt, O., 2014.

Epidemiology and estimated costs of a large waterborne outbreak of norovirus infection in Sweden. Epidemiology and Infection 142(03), 592-600.

Marshall, J.A., Salamone, S., Yuen, L., Catton, M.G. and Wright, J.P., 2001. High level excretion of Norwalk-like virus following resolution of clinical illness. Pathology 33(1), 50-52.

McGee, P., Bolton, D.J., Sheridan, J.J., Earley, B., Kelly, G. and Leonard, N., 2002. Survival of Escherichia coli $\mathrm{O} 157: \mathrm{H} 7$ in farm water: its role as a vector in the transmission of the organism within herds. Journal of Applied Microbiology 93(4), 706-713.

Mead, P.S., Slutsker, L., Dietz, V., McCaig, L.F., Bresee, J.S., Shapiro, C., Griffin, P.M. and Tauxe, R.V., 1999. Food-related illness and death in the United States. Emerging infectious diseases 5(5), 607.

Medema, G., Schets, F., Teunis, P. and Havelaar, A., 1998. Sedimentation of Free and Attached Cryptosporidium Oocysts and Giardia Cysts in Water. Applied and environmental microbiology 64(11), 4460-4466.

Medema, G.J., Bahar, M. and Schets, F.M., 1997. Survival of Cryptosporidium parvum, Escherichia coli, faecal enterococci and Clostridium perfringens in river water: influence of temperature and autochthonous microorganisms. Water Science and Technology 35(11), 249-252. 
Mokhtari, A. and Frey, H.C., 2005. Recommended Practice Regarding Selection of Sensitivity Analysis Methods Applied to Microbial Food Safety Process Risk Models. Human and Ecological Risk Assessment: An International Journal 11(3), 591-605.

Nasser, A.M., Zaruk, N., Tenenbaum, L. and Netzan, Y., 2003. Comparative survival of Cryptosporidium, coxsackievirus A9 and Escherichia coli in stream, brackish and sea waters. Water Science and Technology 47(3), 91.

Norwegian Water BA, 2009. Optimal disinfection practice phase 2, (In norwegian: Optimal desinfeksjonspraksis fase 2), http://vav.griffel.net/filer/C_169-2009.pdf, Norwegian Water BA, Hamar.

NZMH, 2014. Water Safety Plan Guides for Drinking Water Supplies, New Zeeland Ministry of Health, Wellington.

Oliver, D.M., Porter, K.D.H., Pachepsky, Y.A., Muirhead, R.W., Reaney, S.M., Coffey, R., Kay, D., Milledge, D.G., Hong, E., Anthony, S.G., Page, T., Bloodworth, J.W., Mellander, P.-E., Carbonneau, P.E., McGrane, S.J. and Quilliam, R.S., 2016. Predicting microbial water quality with models: Overarching questions for managing risk in agricultural catchments. Science of The Total Environment $544,39-47$.

Ottoson, J. and Stenström, T.A., 2003. Faecal contamination of greywater and associated microbial risks. Water research 37(3), 645-655.

Ottosson, J. and Stenström, T.A., 2003. Growth and reduction of microorganisms in sediments collected from a greywater treatment system. Letters in Applied Microbiology 36(3), 168-172. Payment, P. and Hunter, P.R., 2001. Endemic and epidemic infectious intestinal disease and its relationship to drinking water, Ch 4 in Water quality: guidelines, standard and health, pp. 61-88, IWA Publishing World Health Organization, London.

Petterson, S.R., Mitchell, V.G., Davies, C.M., O'Connor, J., Kaucner, C., Roser, D. and Ashbolt, N., 2016. Evaluation of three full-scale stormwater treatment systems with respect to water yield, pathogen removal efficacy and human health risk from faecal pathogens. Science of The Total Environment 543, Part A, 691-702. 
PHAS, 2017. Statistics on Illness, (In Swedish: Sjukdomsstatistik),

https://www.folkhalsomyndigheten.se/folkhalsorapportering-statistik/statistikdatabaser-och-

visualisering/sjukdomsstatistik/, The Public Health Agency of Sweden Accessed: 2017, March 13.

Rhodes, M.W. and Kator, H., 1988. Survival of Escherichia coli and Salmonella spp. in estuarine environments. Applied and environmental microbiology 54(12), 2902-2907.

Rizak, S., Cunliffe, D., Sinclair, M., Vulcano, R., Howard, J., Hrudey, S. and Callan, P., 2003.

Drinking water quality management: a holistic approach. Water Science \& Technology 47(9), 31-36.

Rosén, L., Back, P.-E., Söderqvist, T., Norrman, J., Brinkhoff, P., Norberg, T., Volchko, Y., Norin, M., Bergknut, M. and Döberl, G., 2015. SCORE: A novel multi-criteria decision analysis approach to assessing the sustainability of contaminated land remediation. Science of The Total Environment 511, 621-638.

Rosén, L., Lindhe, A., Chenoweth, J., Kelay, T., Fife-Schaw, C. and Beuken, R., 2010. Decision support for risk management in drinking water supply: Overview and framework, https://www.techneau.org/fileadmin/files/Publications/Publications/Deliverables/D4.4.1-Report.pdf, TECHNEAU.

Schijven, J., Bouwknegt, M., de Roda Husman, A.M., Rutjes, S., Sudre, B., Suk, J.E. and Semenza, J.C., 2013. A Decision Support Tool to Compare Waterborne and Foodborne Infection and/or Illness Risks Associated with Climate Change. Risk Analysis 33(12), 2154-2167.

Schijven, J.F., Mülschlegel, J.H.C., Hassanizadeh, S.M., Teunis, P.F.M. and de Roda Husman, A.M., 2006. Determination of protection zones for Dutch groundwater wells against virus contamination uncertainty and sensitivity analysis. Journal of Water and Health 4(3), 297-312.

SEPA, 1991. Treatment of household wastewater, (In Swedish: Rening av hushålsspillvatten), http://www.naturvardsverket.se/Documents/allmrad/ar-91-2.pdf, Swedish Environmental Protection Agency, Stockholm.

SEPA, 2002. Robust, sustainable small on-site wastewater systems - A review., In Swedish: Robusta, uthålliga små avloppssystem - En kunskapssammanställning.

http://www.naturvardsverket.se/Documents/publikationer/620-5224-1.pdf?pid=2891, Swedish Environmental Protection Agency, Stockholm. 
SEPA, 2003. Small on-site wastewater systems, (In Swedish: Små avloppsanläggningar),

https://www.naturvardsverket.se/upload/stod-i-miljoarbetet/vagledning/avlopp/faktablad-8147-enskiltavlopp/faktablad-8147-sma-avloppsanlaggningar.pdf, Swedish Environmental Protection Agency, Stockholm.

SEPA, 2004. Knowledge of on-site wastewater treatment systems in Swedish municipalities, (In Swedish: Kunskapsläget om enskilda avlopp i Svenska kommuner) Stockholm.

SEPA, 2008a. Cross-section charge system proposal for nitrogen and phosphorous, (In Swedish:

Förslag till avgiftssystem för kväve och fosfor), http://www.naturvardsverket.se/upload/stod-imiljoarbetet/vagledning/avlopp/faktablad-8147-enskilt-avlopp/faktablad-8147-smaavloppsanlaggningar.pdf, Swedish Environmental Protection Agency, Stockholm. SEPA, 2008b. Small on-site wastewater systems - Guidebook on general advices, (In Swedish: Små avloppsanläggningar - Handbok till allmänna råd), https://www.havochvatten.se/download/18.5f66a4e81416b5e51f7c41/1381136453410/handbok-smaavloppsanlaggningar.pdf, Swedish Environmental Protection Agency, Stockholm.

SEPA, 2013. Sustainable recycling of phosphorous, (In Swedish: Hållbar återföring av fosfor), http://www.naturvardsverket.se/Documents/publikationer6400/978-91-620-6580-5.pdf, Swedish Environmental Protection Agency, Stockholm.

SEPA, 2015. Guidence and application of efficient regulation of small on-site wastewater treatment systems, (In Swedish: Vägledning och exempel för effektiv tillsyn av små avlopp) http://www.naturvardsverket.se/upload/stod-i-miljoarbetet/vagledning/avlopp/faktablad-8147-enskiltavlopp/faktablad-8147-sma-avloppsanlaggningar.pdf, Stockholm.

SEPA, 2017. EU demands on Swedish wastewater treatment plants, (In Swedish: EU-krav på svenska avloppsreningsverk), http://www.naturvardsverket.se/Stod-i-

miljoarbetet/Rattsinformation/Rattsfall/Avloppsreningsverk/EU-krav-pa-svenska-avloppsreningsverk/, Swedish Environmental Protection Agency, Accessed: 2017, February 3.

Sjöbo Municipality, 2016a. Fee for waste removal services 2016, Sjöbo municipality, In Swedish: Avfallstaxa, Sjöbo kommun 
873 http://www.sjobo.se/files/Bygga,\%20bo\%20och\%20milj\%C3\%B6/Avfall/F\%C3\%B6rslag\%20till\%20

874 Avfallstaxa\%202016.pdf, Accessed: 2016, Juli 6 Sjöbo municipality.

875 Sjöbo Municipality, 2016b. Fee for water and wastewater services 2016, Sjöbo municipality, In

876 Swedish: VA-taxa, Sjöbo kommun

877 http://www.sjobo.se/files/Bygga,\%20bo\%20och\%20milj\%C3\%B6/Vatten\%20och\%20avlopp/Kommu

878 nalt\%20vatten\%20och\%20avlopp/VA-taxa\%202016.pdf, Accessed: 2016, Juli 6 Sjöbo municipality.

879 Sjöbo Municipality, 2016c. Information and instructions for expanding municipal water and

880 wastewater services in Sjöbo sommarby, Sjöbo municipality, In Swedish: Information och

881 anvisningar vid utbyggnad av vatten- och avloppsnät i Sjöbo sommarby, Sjöbo kommun

882 http://www.sjobo.se/files/Bygga,\%20bo\%20och\%20milj\%c3\%b6/Vatten\%20och\%20avlopp/Kommun

883 alt\%20vatten\%20och\%20avlopp/Sj\%c3\%b6bo\%20sommarby/Information\%20och\%20anvisningar\%2

884

885

886

887

888

889

890

891

892

893

894

895

896

897

898

899

0vid\%20utbyggnad.pdf, Accessed: 2016, Juli 2 Sjöbo municipality.

SMHI, 2017. Vattenwebb, http://vattenwebb.smhi.se/, Swedish Meteorological and Hydrological

Institute Accessed: 2017, February 28.

STA, 2016. Method and socioeconomical calculation vavlues for the transport sector: ASEK 6.0,

Analysmetod och samhällsekonomiska kalkylvärden för transportsektorn: ASEK 6.0

https://www.trafikverket.se/contentassets/4b1c1005597d47bda386d81dd3444b24/hela_dokumentet_as ek_6_0.pdf, Borlänge.

Sundahl, A.-C., Wennberg, C., Tilly, L., Wettemark, F., Magnusson, P. and Schuster, J., 2008.

Vombsjön - a Water Framework Directive project, (In Swedish: Vombsjön - ett ramdirektivprojekt).

VATTEN (64), 129-136.

Svensson, M., Nilsson, F.O.L. and Arnberg, K., 2015. Reimbursement Decisions for Pharmaceuticals

in Sweden: The Impact of Disease Severity and Cost Effectiveness. PharmacoEconomics 33(11), $1229-1236$.

Swaffer, B.A., Vial, H.M., King, B.J., Daly, R., Frizenschaf, J. and Monis, P.T., 2014. Investigating source water Cryptosporidium concentration, species and infectivity rates during rainfall-runoff in a multi-use catchment. Water research 67, 310-320. 
900

901

902

903

904

905

906

907

908

909

910

911

912

913

914

915

916

917

918

919

920

921

922

923

924

925

926

Terzieva, S.I. and McFeters, G.A., 1991. Survival and injury of Escherichia coli, Campylobacter jejuni, and Yersinia enterocolitica in stream water. Canadian Journal of Microbiology 37(10), 785790.

Teunis, P., Van den Brandhof, W., Nauta, M., Wagenaar, J., Van den Kerkhof, H. and Van Pelt, W., 2005. A reconsideration of the Campylobacter dose-response relation. Epidemiology and Infection 133(04), 583-592.

Teunis, P.F.M., Chappell, C.L. and Okhuysen, P.C., 2002. Cryptosporidium Dose Response Studies: Variation Between Isolates. Risk Analysis 22(1), 175-185.

Teunis, P.F.M., Moe, C.L., Liu, P., E. Miller, S., Lindesmith, L., Baric, R.S., Le Pendu, J. and Calderon, R.L., 2008. Norwalk virus: How infectious is it? Journal of Medical Virology 80(8), 14681476.

Wastewater guide, 2016. Is your onsite sewage system green, yellow or red? (How to classify your onsite sewage system), In Swedish: Är ditt avlopp grönt, gult eller rött?

http://husagare.avloppsguiden.se/svea/avloppsguiden_checklista_avlopp_v2.pdf, Accessed: 2016, Juli 2.

Westrell, T., 2004. Microbial risk assessment and its implications for risk management in urban water systems. Doctoral Thesis, Linköping University Electronic Press, Linköping.

Westrell, T., Andersson, Y. and Stenström, T.A., 2006. Drinking water consumption patterns in Sweden. Journal of Water and Health 4(4), 511-522.

WHO, 2001. Water Quality - Guidelines, Standards \& Health: Assessment of risk and risk management for water-related infectious disease, IWA publishing, World Health Organization,

Geneva.

WHO, 2011. Guidelines for drinking-water quality, 4th edition, World Health Organization, Geneva. WHO, 2016. Quantitative microbial risk assessment: Application for water safety management, World Health Organization, Geneva.

Wyman, J., Heaton, K., Manning, A. and Wicks, A., 1978. Variability of colonic function in healthy subjects. Gut 19(2), 146-150. 
- A decision model for drinking water context, combining QMRA and CBA, was developed.

- This flexible model can be tailored to different systems and decision problems.

- The microbial risk mitigation measures were compared in a Swedish case-study.

- Microbial risk reduction was measured in QALYs and monetised.

- This novel decision model provides transparent and holistic decision support. 